\title{
Multi-Dimensional Analyses Reveal Unequal Resource, Economic, and Environmental Gains and Losses among the Global Aluminum Trade Leaders
}

Wanjun Wang, ${ }^{\mathrm{a}, \mathrm{b}, \mathrm{c}}$, Wei-Qiang Chen ${ }^{\mathrm{a}, \mathrm{b}, \mathrm{c}^{*}}$, Zhou-Wei Diao $^{\mathrm{d}}$, Luca Ciaccie, Leila Pourzahedi ${ }^{\mathrm{f}}$, Matthew J. Eckelman ${ }^{\mathrm{f}}$, Yi Yangg,h, and Lei Shi ${ }^{{ }^{*}}$

${ }^{a}$ Key Lab of Urban Environment and Health, Institute of Urban Environment, Chinese Academy of Sciences, 1799 Jimei Road, Xiamen, Fujian, 361021, China

${ }^{b}$ University of Chinese Academy of Sciences, Beijing, 100049, China

${ }^{c}$ Fujian Institute of Innovation, 1799 Jimei Road, Xiamen, Fujian, 361021, China

${ }^{d}$ BP (China) Investment Company Limited., Beijing, 100020, China

${ }^{e}$ Department of Industrial Chemistry “Toso Montanari”, Alma Mater Studiorum-University of Bologna, Bologna, 40136, Italy

$f$ Department of Civil and Environmental Engineering, Northeastern University, Massachusetts 02115, USA

${ }^{g}$ Key Laboratory of the Three Gorges Reservoir Region's Eco-Environment, Ministry of Education, Chongqing University, Chongqing 400045, China

${ }^{\boldsymbol{h}}$ Environmental Studies Program, Dartmouth College, Hanover, NH 03755, USA

${ }^{i}$ State Key Joint Laboratory of Environmental Simulation and Pollution Control, School of Environment, Tsinghua University, Beijing 100084, China

*Correspondence to: Wei-Qiang Chen (wqchen@iue.ac.cn) and Lei Shi (lone@tsinghua.edu.cn) 


\section{Content}

1 Life Cycle of Aluminum in the Anthroposphere and Its Life Cycle Analysis Boundary ................................S4

2 The List of Aluminum-Containing Products and Their Aluminum Content ...................................................S5

3 Calculation Process of Direct and Indirect Trade Flows ………..................................................................

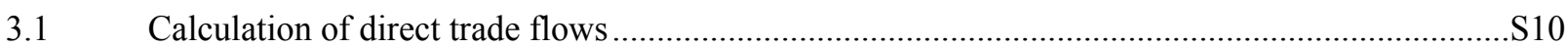

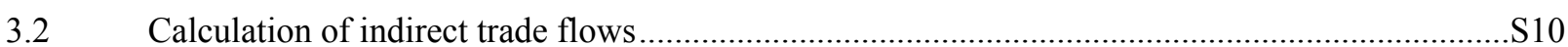

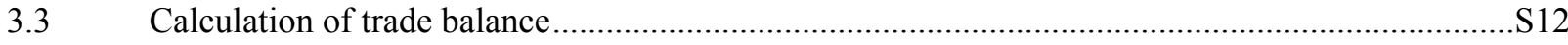

4 Coefficients of Energy Use and GHG Emissions for Aluminum ............................................................. 13

4.1 Coefficients of Energy Use and GHG Emissions for Raw Material and Semis Products ...............S13

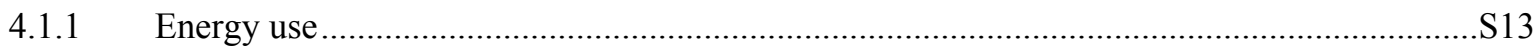

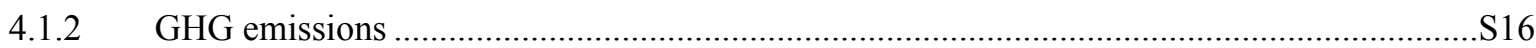

4.1.3 Converting process incremental data into CTP data ............................................................ 17

4.2 Estimating Method of Incremental Energy Use and GHG Emissions for Manufacturing Process S17

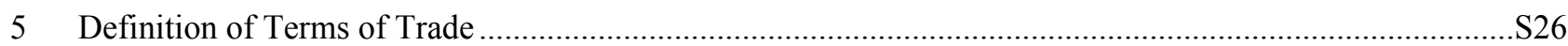

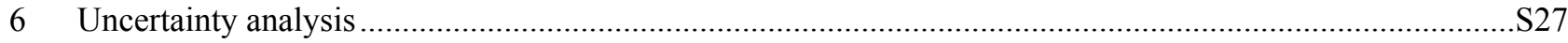

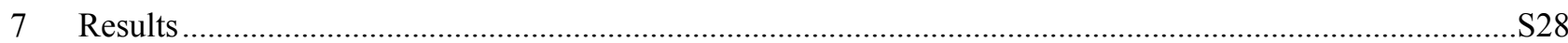

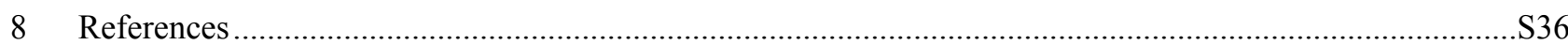

Figure S1: Schematic diagram for the anthropogenic aluminum life cycle and its LCA boundary.

Figure S2. Data sources and process for calculating the monetary trade volume (MTV), physical trade volume (PTV), and energy use and GHG emissions embodied in the trade of aluminum contained in a specific aluminumcontaining product (ACP).

Figure S3: Basic structure of an economic input-output table.

Figure S4 The average, bottom, and top value of PTB, MTB, EUB, and GEB for (b) China, (c) Japan, and (d) Australia from 1991 to 2016.

Figure S5 Aluminum trade balance in resource, economic, energy and environmental consequences for these four countries.

Figure S6 Net import of aluminum embedded in different product groups measured by mass for (a) the US, (b) China, (c) Japan, and (d) Australia from 1991 to 2016.

Figure S7 Money earned by trade of different ACP groups for (a) US, (b) China, (c) Japan, and (d) Australia from 1991 to 2016.

Figure S8 Net import of embodied energy in aluminum trade for (a) US, (b) China, (c) Japan, and (d) Australia from 1991 to 2016.

Figure S9. Net import of embodied GHG emissions in aluminum trade for (a) US, (b) China, (c) Japan, and (d) Australia from 1991 to 2016.

Figure S10 The seven ACP groups' commodity terms of trade of these four countries. CTOT $=$ Commodity terms of trade; Linear fit of CTOT shows the trend of each of ACP's CTOT.

Figure S11 The seven ACP groups' energy terms of trade of these four countries...

Figure S12 The seven ACP groups' pollution terms of trade of these four countries. PTOT $=$ Pollution terms of trade; Linear fit of PTOT shows the trend of each of ACP's PTOT. 
Table S1: The list of aluminum-containing products (ACPs) in the international trade and their aluminum concentration data

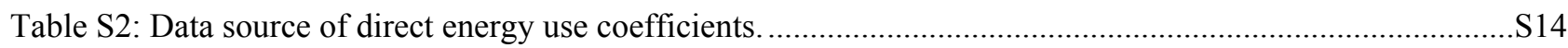

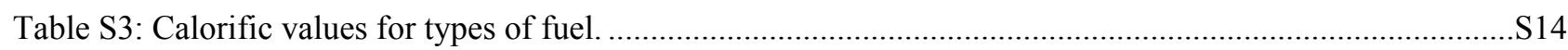

Table S4: Coefficients of energy input in petrol coke and pitch production. ....................................................... 15

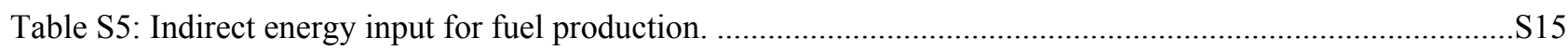

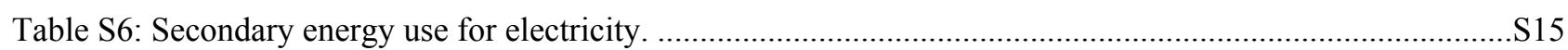

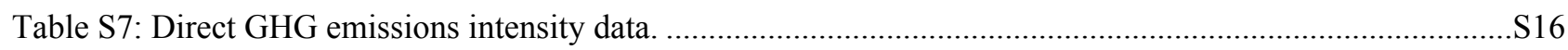

Table S8: Emission factors for calculating process $\mathrm{CO}_{2}$ emissions from petrol coke and pitch production...........S16

Table S9: Emission factors for calculating process $\mathrm{CO}_{2}$ emissions from Paste/Anode consumption. ...................S16

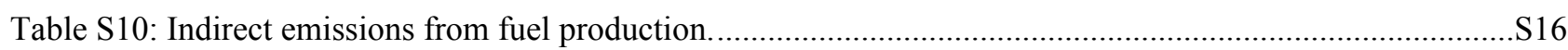

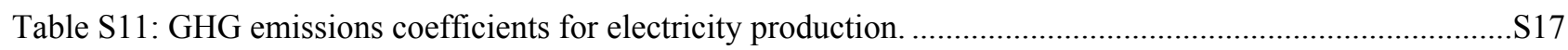

Table S12: Factors to convert process incremental data into CTP data................................................................. 17

Table S13: The conversion table between finished ACPs and IO sectors of US, Japan, and Australia.................S20 


\section{Life Cycle of Aluminum in the Anthroposphere and Its Life Cycle Analysis Boundary}

The life cycle of aluminum in the anthroposphere can be seen in Figure S1, which is composed of eight life stages: Mining, Refining, Smelting, Fabrication, Manufacturing, Use, Collection \& Pretreating, and Recycling. Except Use stage, each of these life stages can produce aluminum-containing products (ACPs) to be traded between countries. These APCs can be seen in table S1. More detailed information about life cycle of aluminum can be seen in the former research ${ }^{1}$.

Different from life cycle of aluminum, the boundary of aluminum LCA study also contains Paste/Anode production process and Energy generation process. Energy use and GHG emissions from Mining, Refining, Paste/Anode production, Smelting, Fabrication, Manufacturing, Collection \& Pretreating, and recycling compose the direct energy use and GHG emissions. Indirect energy use and GHG emissions are from energy (both electricity and fuel) generation processes. GHG emissions not only contain carbon dioxide emissions but also perfluorocarbons (PFCs) emissions from smelting process.

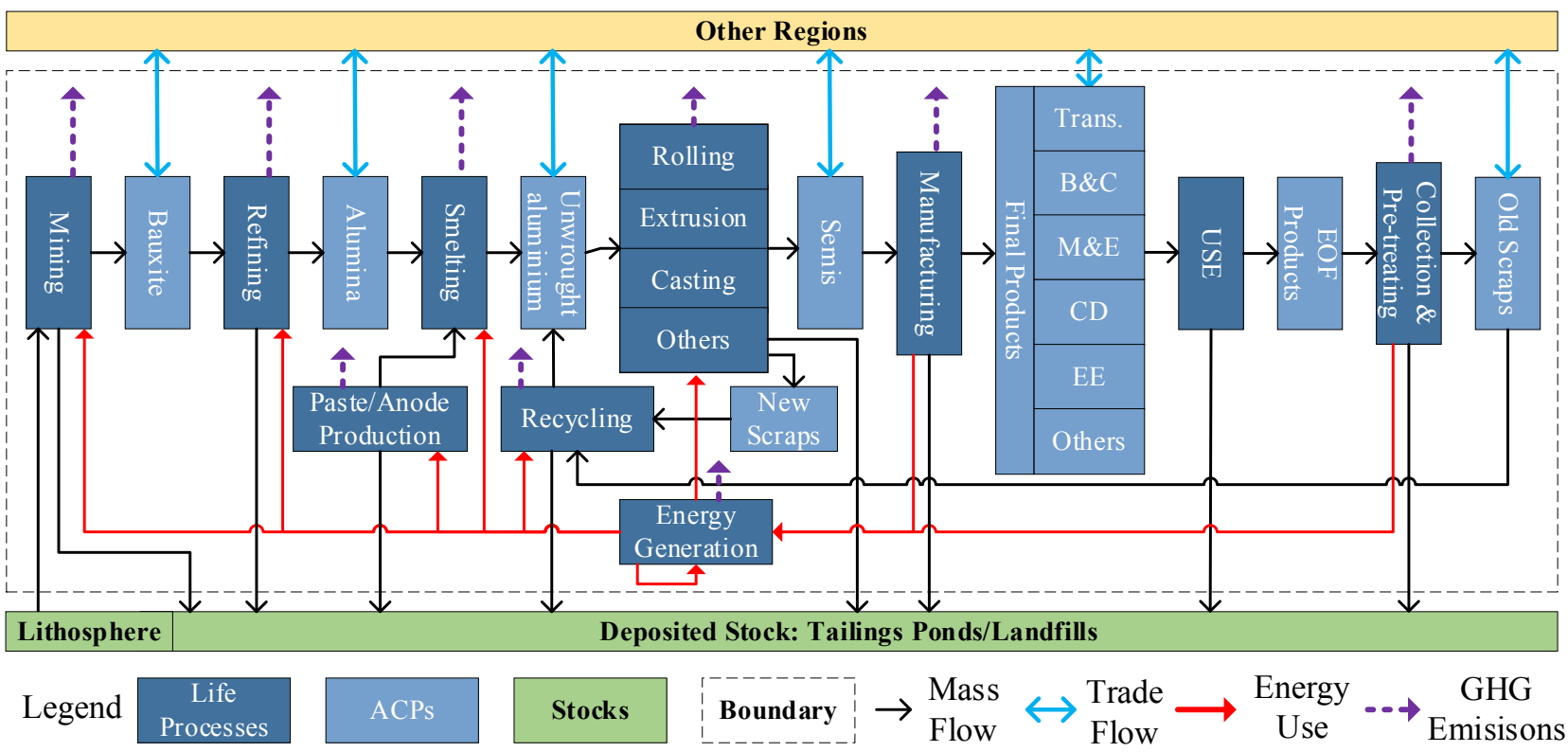

Figure S1: Schematic diagram for the anthropogenic aluminum life cycle and its LCA boundary. 


\section{The List of Aluminum-Containing Products and Their Aluminum Content}

There are 143 items of APCs had been accounted. All the APCs have been divided into six group according to the life stages which can be seen in Table S1. They are Bauxite (2 items), Alumina (1 item), EOL products \& Scrap (1 item), Unwrought aluminum (1 item), Semis (6 items), Finished products (132 items). For the finished APCs, based on their applications, we divide them into Transportation (29 items), Building \& Construction (6 items), Machinery \& Equipment (33 items), Consumer Durables (48 items), Electrical Engineering ( 7 items), and others ( 9 items). Codes of ACPs are SITC 1 codes, which is the first version of Standard International Trade Classification. The aluminum concentration for ACPs are also shown in Table SI, and data sources can be found in former research $^{2,3}$.

Table S1: The list of aluminum-containing products (ACPs) in the international trade and their aluminum concentration data.

\begin{tabular}{|c|c|c|c|c|c|c|}
\hline \multirow{2}{*}{ Life Stage } & \multirow{2}{*}{$\begin{array}{c}\text { Categories of } \\
\text { ACPs }\end{array}$} & \multirow{2}{*}{ SITC1 } & \multirow{2}{*}{ Commodity Name } & \multicolumn{3}{|c|}{ Al Content $(\%)$} \\
\hline & & & & Average & Bottom & Top \\
\hline \multirow{2}{*}{ Mining } & \multirow{2}{*}{ Bauxite } & 2833 & Bauxite and concentrates of aluminum & 27.8 & 23.8 & 31.8 \\
\hline & & $28401^{\mathrm{a}}$ & Ash and residues bearing nonferrous metals & 50 & 40 & 60 \\
\hline Refining & Alumina & 51365 & Aluminum oxide and hydroxide & 43.2 & 34.3 & 52.1 \\
\hline $\begin{array}{l}\text { Collection \& } \\
\text { Pre-treating }\end{array}$ & $\begin{array}{l}\text { EOL products \& } \\
\text { Scrap }\end{array}$ & 28404 & Aluminum waste and scrap & 84 & 80 & 88 \\
\hline $\begin{array}{l}\text { Smelting \& } \\
\text { Recycling }\end{array}$ & $\begin{array}{l}\text { Unwrought } \\
\text { Aluminum }\end{array}$ & 6841 & Aluminum and aluminum alloys, unwrought & 95.8 & 92 & 99.5 \\
\hline \multirow{7}{*}{ Fabrication } & $\begin{array}{l}\text { Semis: Sheets \& } \\
\text { Plates }\end{array}$ & 68422 & Plates, sheets and strip of aluminum & 95 & 91 & 99 \\
\hline & Semis: Foil & 68423 & Aluminum foil & 74 & 49 & 99 \\
\hline & \multirow{3}{*}{ Semis: Extrusions } & 68421 & Bars,rods, angles,shapes and wire of aluminum & 97 & 95 & 99 \\
\hline & & 68425 & Tubes,pipes \& blanks, hollow bars of aluminum & 98 & 97 & 99 \\
\hline & & 68426 & Tube and pipe fittings of aluminum & 97 & 97 & 97 \\
\hline & Castings & - & - & - & - & - \\
\hline & Semis: Others & 68424 & Aluminum powders and flakes & 99 & 99 & 99 \\
\hline \multirow{4}{*}{$\begin{array}{l}\text { Manufacturin } \\
\mathrm{g}\end{array}$} & \multirow{4}{*}{$\begin{array}{l}\text { Transportation, } \\
\text { Air }\end{array}$} & 7114 & Aircraft incl jet propulsion engines & 75 & 75 & 75 \\
\hline & & 7341 & Aircraft, heavier than air & 67.5 & 60 & 75 \\
\hline & & 7349 & Parts of aircraft, balloons airships & 67.5 & 60 & 75 \\
\hline & & 89999 & Catapults and sim. aircraft launching gear, etc. & 75 & 75 & 75 \\
\hline
\end{tabular}




\begin{tabular}{|c|c|c|c|c|c|}
\hline \multirow{3}{*}{$\begin{array}{l}\text { Transportation, } \\
\text { Marine }\end{array}$} & 7351 & Warships of all kinds & 2 & 1 & 3 \\
\hline & 7353 & Ships and boats, other than warships & 2 & 1 & 3 \\
\hline & 7359 & Special purpose ships and boats & 2 & 1 & 3 \\
\hline \multirow{8}{*}{$\begin{array}{l}\text { Transportation, } \\
\text { Rail }\end{array}$} & 71966 & Railway \& tramway track fixtures \& fittings & 3 & 3 & 3 \\
\hline & 7311 & Railway locomotives steam and tenders & 3 & 3 & 3 \\
\hline & 7312 & Electric railway locomotives, not self generat. & 3 & 3 & 3 \\
\hline & 7313 & Railway locomotives, not steam or electric & 3 & 3 & 3 \\
\hline & 7314 & Mechanically propelled railway and tramway cars & 3 & 3 & 3 \\
\hline & 7315 & Rail \& tram passenger cars not mech propelled & 3 & 3 & 3 \\
\hline & 7316 & Rail.\&tram.freight cars,not mechanically propd. & 3 & 3 & 3 \\
\hline & 7317 & Parts of railway locomotives \& rolling stock & 3 & 3 & 3 \\
\hline \multirow{12}{*}{$\begin{array}{l}\text { Transportation, } \\
\text { Road }\end{array}$} & 7321 & Passenger motor cars, other than buses & \multicolumn{3}{|c|}{ vary in time and region } \\
\hline & 7322 & Buses, including trolleybuses & \multicolumn{3}{|c|}{ vary in time and region } \\
\hline & 7323 & Lorries and trucks, including ambulances, etc. & 5.9 & 5.9 & 5.9 \\
\hline & 7324 & Special purpose lorries, trucks and vans & 5.9 & 5.9 & 5.9 \\
\hline & 7325 & Road tractors for tractor trailer combinations & 3.7 & 3.6 & 3.8 \\
\hline & 7326 & Chassis with engs. Mntd. For vehicles of 732.1 & \multicolumn{3}{|c|}{ vary in time and region } \\
\hline & 7327 & Other chassis with engines mounted & \multicolumn{3}{|c|}{ vary in time and region } \\
\hline & 7328 & Bodies \& parts motor vehicles ex motorcycles & \multicolumn{3}{|c|}{ vary in time and region } \\
\hline & 7329 & Motorcycles, motorized cycles and their parts & 21 & 12 & 30 \\
\hline & 7331 & Bicycles \& other cycles, not motorized, \& parts & 20 & 20 & 20 \\
\hline & 7333 & Trailers \& oth vehicles not motorized, \& parts & 7.55 & 7.5 & 7.6 \\
\hline & 7334 & Invalid carriages & 20 & 20 & 20 \\
\hline \multirow{2}{*}{$\begin{array}{l}\text { Transportation, } \\
\text { application parts }\end{array}$} & 7113 & Steam engines and steam turbines & 2 & 2 & 2 \\
\hline & 7115 & Internal combustion engines, not for aircraft & \multicolumn{3}{|c|}{ vary in time and region } \\
\hline \multirow{6}{*}{$\begin{array}{l}\text { Building \& } \\
\text { Construction } \\
(\mathrm{B} \& \mathrm{C})\end{array}$} & 6324 & Builders woodwork \& prefab. Buildings of wood & 10 & 10 & 10 \\
\hline & 6912 & Fin.structural parts \& structures of aluminium & 99 & 99 & 99 \\
\hline & 6913 & Wire,cables,ropes etc.not insulated,aluminium & 99 & 99 & 99 \\
\hline & 69882 & Flexible tubing and piping of base metal & 30 & 30 & 30 \\
\hline & 69884 & Bells (non electric), of base metal & 30 & 30 & 30 \\
\hline & 69886 & Name plates,sign plates,etc.of base metal & 30 & 30 & 30 \\
\hline \multirow{13}{*}{$\begin{array}{l}\text { Machinery } \\
\text { Equipment } \\
(\mathrm{M} \& \mathrm{E})\end{array}$} & 7111 & Steam generating boilers & 0.5 & 0.5 & 0.5 \\
\hline & 7112 & Boiler house plant & 0.5 & 0.5 & 0.5 \\
\hline & 7121 & Agricultural machinery for cultivating the soil & 1 & 1 & 1 \\
\hline & 7122 & Agricultural machinery for harvesting,threshing & 1 & 1 & 1 \\
\hline & 7123 & Milking machines,cream separators,dairy farm eq & 1 & 1 & 1 \\
\hline & 7125 & Tractors, other than road tractors & 3.7 & 3.6 & 3.8 \\
\hline & 7129 & Agricultural machinery and appliances, nes & 1 & 1 & 1 \\
\hline & 7151 & Machine tools for working metals & 2 & 2 & 2 \\
\hline & 7152 & Other metalworking machinery & 2 & 2 & 2 \\
\hline & 7171 & Textile machinery & 2 & 2 & 2 \\
\hline & 7172 & Machinery ex.sewing mach. For working hides etc & 2 & 2 & 2 \\
\hline & 7173 & Sewing machines & 2 & 2 & 2 \\
\hline & 7181 & Paper mill and pulp mill machinery, etc. & 2 & 2 & 2 \\
\hline
\end{tabular}




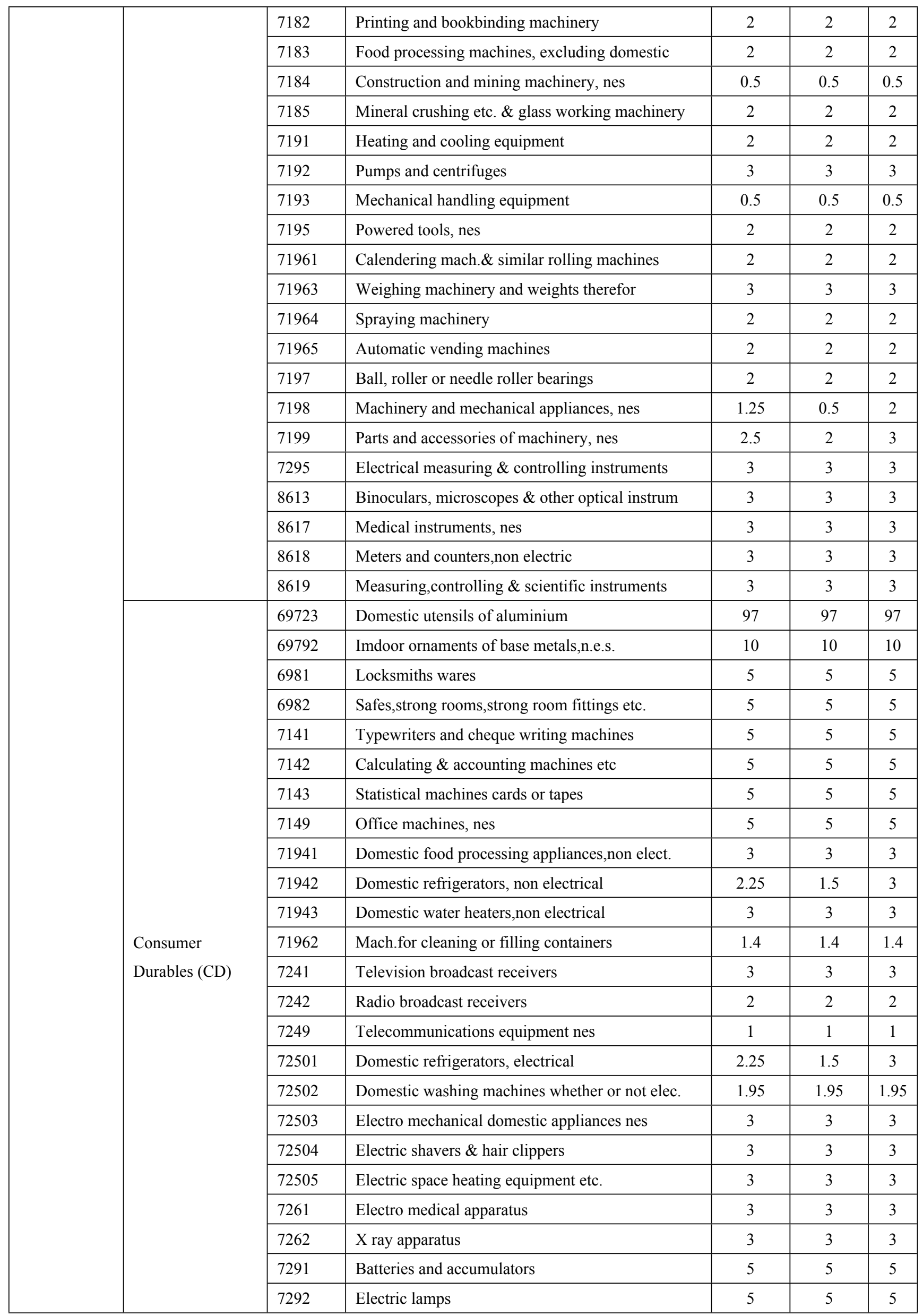




\begin{tabular}{|c|c|c|c|c|c|}
\hline & 7293 & Thermionic valves and tubes, transistors, etc. & 3 & 3 & 3 \\
\hline & 7294 & Automotive electrical equipment & 5 & 5 & 5 \\
\hline & 7296 & Electro mechanical hand tools & 5 & 5 & 5 \\
\hline & 7297 & Electron and proton accelerators & 5 & 5 & 5 \\
\hline & 7299 & Electrical machinery and apparatus, nes & 5 & 5 & 5 \\
\hline & 8124 & Lighting fixtures and fittings and parts & 2 & 2 & 2 \\
\hline & 8210 & Furniture & 3 & 3 & 3 \\
\hline & 8413 & Apparel and clothing accessories of leather & 3 & 3 & 3 \\
\hline & 8612 & Spectacles and spectacle frames & 25 & 25 & 25 \\
\hline & 8614 & Photographic cameras and flashlight apparatus & 5 & 5 & 5 \\
\hline & 8615 & Cine. Cameras, projectors, sound recorders etc. & 5 & 5 & 5 \\
\hline & 8616 & Photographic \& cinematographic equipment nes & 5 & 5 & 5 \\
\hline & 8641 & Watches, watch movements and cases & 10 & 10 & 10 \\
\hline & 8642 & Clocks, clock movements and parts & 10 & 10 & 10 \\
\hline & 8911 & Phonographs, tape \& other sound recorders etc. & 1 & 1 & 1 \\
\hline & 8914 & Pianos and other string musical instruments & 10 & 10 & 10 \\
\hline & 8918 & Musical instruments, nes & 10 & 10 & 10 \\
\hline & 8919 & Parts and accessories of musical instruments & 10 & 10 & 10 \\
\hline & 8941 & Baby and invalid carriages not motorized & 1 & 1 & 1 \\
\hline & 8942 & Childrens toys, indoor games, etc. & 1 & 1 & 1 \\
\hline & 8944 & Other sporting goods & 1 & 1 & 1 \\
\hline & 8945 & Fair ground amusements, etc. & 1 & 1 & 1 \\
\hline & 8951 & Office and stationery supplies of base metals & 10 & 10 & 10 \\
\hline \multirow{7}{*}{$\begin{array}{l}\text { Electrical } \\
\text { Engineering (EE) }\end{array}$} & 7116 & Gas turbines, other than for aircraft & 2 & 2 & 2 \\
\hline & 7117 & Nuclear reactors & 2 & 2 & 2 \\
\hline & 7118 & Engines, nes & 2 & 2 & 2 \\
\hline & 7221 & Electric power machinery & 3 & 3 & 3 \\
\hline & 7222 & Apparatus for electrical circuits & 3 & 3 & 3 \\
\hline & 7231 & Insulated wire and cable & 3 & 3 & 3 \\
\hline & 7232 & Electrical insulating equipment & 3 & 3 & 3 \\
\hline \multirow{9}{*}{ Others } & 5714 & Hunting and sporting ammunition & 3 & 3 & 3 \\
\hline & 69213 & Tanks,etc.for storage or manuf.use of aluminium & 98 & 98 & 98 \\
\hline & 69222 & Casks,drums,etc.used for transport of aluminium & 98 & 98 & 98 \\
\hline & 69232 & Compressed gas cylinders of aluminium & 98 & 98 & 98 \\
\hline & 69885 & Stoppers,crown corks, bottle caps, of base metal & 40 & 40 & 40 \\
\hline & 69887 & Soldering \& welding rods, etc, of base metal & 40 & 40 & 40 \\
\hline & 69894 & Articles of aluminium,n.e.s. & 95 & 95 & 95 \\
\hline & 6943 & Non military arms & 3 & 3 & 3 \\
\hline & 9510 & Firearms of war \& ammunition thereof & 3 & 3 & 3 \\
\hline
\end{tabular}

a. This data is adjusted by H0-281820 and H0-281830. Because SITC1-28401 includes ash and residues containing other non-ferrous metal except aluminum. 


\section{Calculation Process of Direct and Indirect Trade Flows}

Data gathered through literature review for quantifying direct and indirect trade flows of aluminum contained in each ACP can be grouped into four categories: (1) data on monetary trade volume (MTV) of the ACP measured by US dollars; (2) data on physical trade volume (PTV) of the ACP measured by net weight; (3) data on physical content of aluminum in the ACP; and (4) data on energy use and GHG emissions intensities of aluminum for each process. The detailed calculation processes of PTV, MTV, and embodied energy use and GHG emissions of aluminum in an ACP are as follows.

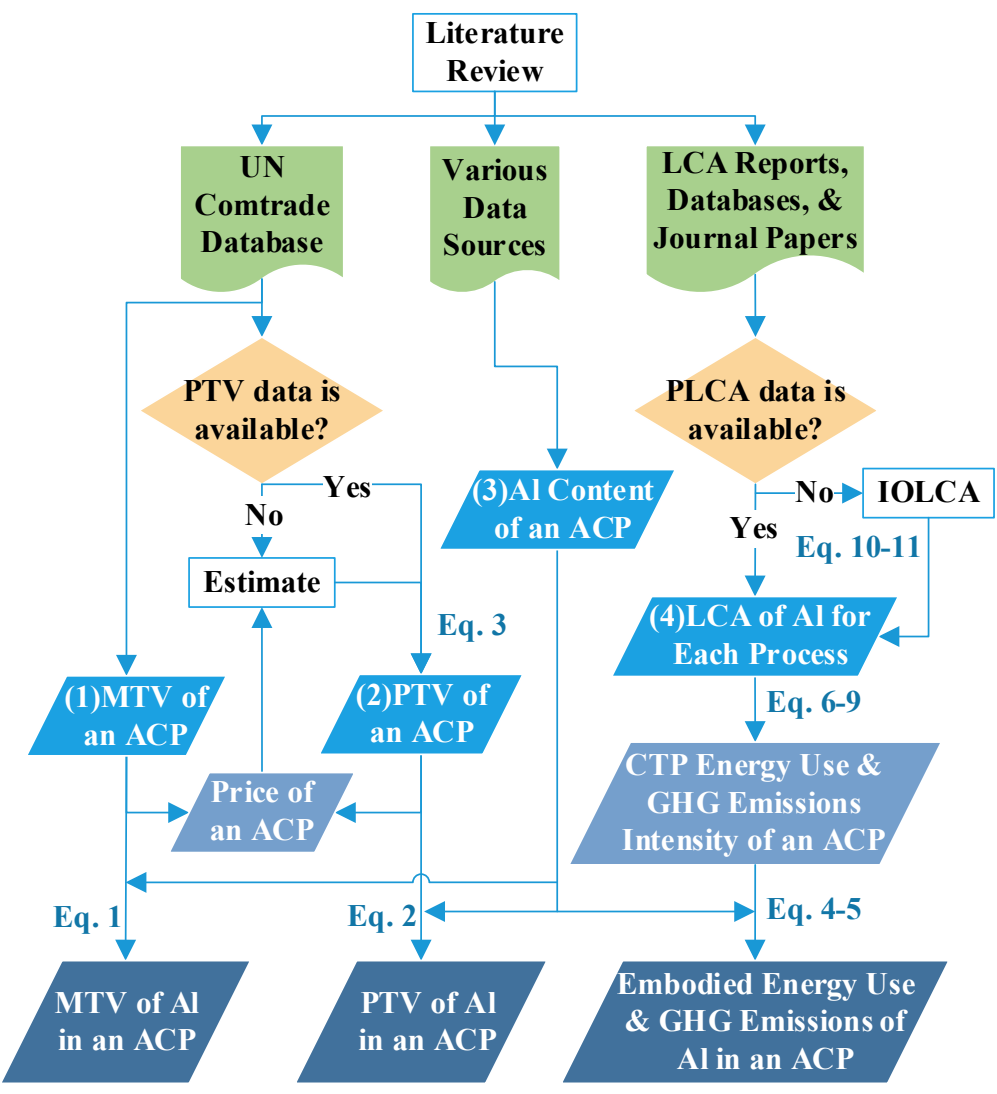

Figure S2. Data sources and process for calculating the monetary trade volume (MTV), physical trade volume (PTV), and energy use and GHG emissions embodied in the trade of aluminum contained in a specific aluminum-containing product (ACP). 


\subsection{Calculation of direct trade flows}

To calculate monetary flow and physical flow of aluminum trade, data in the first, second, and third groups are used. Sources of data on physical aluminum contents in ACPs have been described in detail in our former studies ${ }^{1,2,4}$ and are also available in Table S1. For each ACP, aluminum trade flows measured by monetary value $\left(M F_{A l, i, j}\right)$ and physical value $\left(P F_{A l, i, j}\right)$ are calculated by equations (1), (2), and (3),

$$
\begin{array}{ll} 
& M F_{A l, i, j}=M F_{P, i, j} \times C_{A l, i} \\
\text { PTV data available } & P F_{A l, i, j}=P F_{P, i, j} \times C_{A l, i} \\
\text { PTV data unavailable } & P F_{A l, i, j}=M F_{P, i, j} / P_{P, i, j} \times C_{A l, i}
\end{array}
$$

where $P F_{P, i, j}$ and $M F_{P, i, j}$ indicate physical and monetary value of $A C P_{i}$ in year $j$, respectively, $C_{A l, i}$ denotes the average aluminum content of $A C P_{i}$, and $P_{P, i, j}$ is the price of $A C P_{i}$ in year $j$.

\subsection{Calculation of indirect trade flows}

Two indirect flows that are energy use $\left(E F_{A l, i, j}\right)$ and GHG emissions $\left(G F_{A l, i, j}\right)$ embodied in aluminum for $A C P_{i}$ in year $j$ are calculated by equations (4) and (5), based on data in the first and second groups,

$$
\begin{aligned}
& E F_{A l, i, j}=P F_{A l, i, j} \times E I_{A l, i, j}^{C T P} \\
& G F_{A l, i, j}=P F_{A l, i, j} \times G I_{A l, i, j}^{C T P}
\end{aligned}
$$

where $E I_{A l, i, j}^{C T P}$ and $G I_{A l, i, j}^{C T P}$ indicate cradle to product (CTP) energy use and GHG emissions intensity of aluminum contained in $A C P_{i}$ in year $j$.

Based on the framework in figure $\mathrm{S} 1, E I_{A l, i, j}^{C T P}$ and $G I_{A l, i, j}^{C T P}$ are calculated as the accumulation of the process incremental energy use and GHG emissions intensity (indicated by $E I_{A l, i, j}^{I n c}$ and $G I_{A i, i, j}^{I n c}$ ) of aluminum from bauxite mining process (the start point of aluminum's life cycle) to the process $k$ (the process that the ACP is generated in), as shown in equation (6) and (7). However, $E I_{A l, i, j}^{I n c}$ and $G I_{A i, i, j}^{I n c}$ 
couldn't obtained directly. Energy use and GHG emissions per ACP output in each process (indicated by $E I_{P}^{I n c}$ and $\left.G I_{P}^{I n c}\right)$ is used as supplementary. $E I_{A l, i, j}^{I n c}$ and $G I_{A l, i, j}^{I n c}$ are equal to $E I_{P, i, j}^{I n c}$ and $G I_{P, i, j}^{I n c}$ divided by the average aluminum content of $A C P_{i}$, which can be seen in equation (8) and (9),

$$
\begin{aligned}
& E I_{A l, i, j}^{C T P}=\sum_{i=1}^{k} E I_{A l, i, j}^{I n C} \\
& G I_{A l, i, j}^{C T P}=\sum_{i=1}^{k} E I_{A l, i, j}^{I n C} \\
& E I_{A l, i, j}^{C T P}=\sum_{i=1}^{k} E I_{P, i, j}^{I n C} / C_{A l, i} \\
& G I_{A l, i, j}^{C T P}=\sum_{i=1}^{k} G I_{P, i, j}^{I n C} / C_{A l, i}
\end{aligned}
$$

The key to calculate indirect flows is to obtain reliable data on $E I_{P}^{I n c}$ and $G I_{P}^{I n c}$. Various LCA reports, databases, and papers about energy use and GHG emission for each ACP production process have been searched. Data in the US, ${ }^{5,6} \mathrm{Japan},{ }^{7}$ China, ${ }^{8}$ Australia, Europe,${ }^{9-11}$ and the world average ${ }^{12-}$ ${ }^{16}$ are collected, some of which have time specific data, some not. Those data vary across areas and over time. In comparison, world average data are much complete and accurate. And there is an obvious decline trend over time because of technology improvement, especially in electrolysis process which has the highest energy use and GHG emissions among all the production processes. We use life cycle inventory (LCI) data from aluminum industries (International Aluminum Institute and European Aluminum Association) which collected by process based LCA (PLCA) and build a time series LCI data set to avoid the uncertainties due to improvements in energy efficiency across the industry. Both direct and indirect energy use and GHG emissions are calculated. Energy use and GHG emissions from transportation process are ignored. Life cycle of primary aluminum production and life cycle of EP\&S recycling are seen as two independent systems. Secondary aluminum production process begins with EP\&S collection \& pre-treating rather than bauxite mining. 
Incremental PLCA data in manufacturing process are unavailable. Input-Output Life Cycle Assessment (IOLCA) method is used to explore energy use and GHG emissions intensity in manufacturing process for finished ACPs (indicated by EI Finished ACP and GII Inc calculated by energy use and GHG emissions intensity for industry which finished ACP belongs to. To avoid double counting, only direct energy use and GHG emission for manufacturing process are calculated. Equation (10) and (11) show the calculation processes. EI Finished $A C P_{i, j}$ and $G I_{\text {Finished }}^{I n C C}{ }_{i, j}$ indicates the incremental energy use and GHG emissions intensity of finished ACP $i$ in the year $j ; E I_{\text {Industry }}^{\text {dir }}$, and $G I_{\text {Industry }}^{\text {dir }}, j$ are direct energy use and GHG emissions intensity of industry $m$ in the year $j$; finished ACP $i$ is belongs to industry $m ; P_{P, i, j}$ indexes the price of the ACP $i$ in the year $j$. More details about calculated process can be seen in SI 3.2.

$$
\begin{aligned}
& \text { EI Finished }_{A C P_{i, j}}^{\text {Inc }}=E I_{\text {Industry }}^{\text {dir }}, \times P_{P, i, j} \\
& G I_{\text {Finished }}^{I n C} A C P_{i, j}=G I_{\text {Industry }}^{\text {dir }} \times P_{P, i, j}
\end{aligned}
$$

\subsection{Calculation of trade balance}

Because the direction of the monetary trade flow is the opposite of that of the physical trade flow and the embodied energy use and GHG emission flows (Figure 1), the balance of the MTV of aluminum (MTB) is accounted as the difference between the export flow and the import flow, while the balance of the PTV of aluminum (PTB), of the embodied energy use (EUB), and of the embodied GHG emissions (EEB), is accounted as the difference between the respective import flow and export flow. After determining the volumes and balances of the four trade flows of the aluminum contained in each ACP, total trade volumes and balances of each of the four trade flows can be summed up for each of the six ACPs groups and all ACPs. Equations are as follows,

$$
\begin{aligned}
& M T B_{A l, i, j}=M F_{A l, l, j}^{E x p o r t}-M F_{A l, l, j}^{I m p o r t} \\
& P T B_{A l, i, j}=P F_{A l, l, j}^{I m p o r t}-P F_{A l, l, j}^{E x p o r t}
\end{aligned}
$$




$$
\begin{aligned}
& E U B_{A l, l, j}^{I m p o r t}=E F_{A l, l, j}^{I m p o r t}-E F_{A l, l, j}^{E x p o r t} \\
& G E B_{A l, l, j}^{I m p o r t}=G F_{A l, l, j}^{I m p o r t}-G F_{A l, l, j}^{E x p o r t}
\end{aligned}
$$

\section{Coefficients of Energy Use and GHG Emissions for Aluminum}

\subsection{Coefficients of Energy Use and GHG Emissions for Raw Material and Semis Products}

\subsubsection{Energy use}

Direct energy use coefficients are from International Aluminum Institute (IAI) and European Aluminum (EAA). We prefer to use data from IAI, because these data are world average which can more accurately reflect the energy use and GHG emissions of these four countries' aluminum industries than that from EAA which only show European average. LCI data collected by EAA are acted as complement.

IAI had collected global aluminum industry data for use in LCAs since 1998. These LCI data have been published in years $2000^{12}, 2003^{13}, 2007^{14}, 2013^{15}$, and $2017^{16}$, which report worldwide aluminum production in years $1995-1998,2000,2005,2010$, and 2015. IAI also reports energy intensity and energy consumption of smelting and refining from the year 1980 to $2017^{17}$ and perfluorocarbon emissions in the period 1990-2017. However, IAI LCAs only include five processes: Mining, Refining, Paste/Anode production, Electrolysis, and Ingot casting. For semi-production and secondary aluminum production processes, data from EAA's ecological profile reports are used. EAA has been collected LCA data from European producers and manufacturers since 1992 and a series of reports had been published. Early reports, which published in years 1996, 2000, and 200510, are not available. Fortunately, some data in these early reports had been published in the 2008 version, which can cover data in years 1998, 2002, and 2005. And in 2013 and 2018, EAA reported LCA data in 2010 and $2015^{9,11}$. 
Data from IAI and EAA are not always in the same study period. In order to combine data from IAI and EAA into a timeseries database, some adjusts are needed. The data source of energy use coefficients for each production process are detailed in Table S2-S3.

Indirect energy use intensity is energy input per output in petrol coke and pitch production and energy production. Coefficients for petrol coke and pitch production and coefficients for fuel production can be seen in table S4-S5. IAI provides historical aluminum industry global power mix data on the website, which are used to estimate secondary energy use for electricity. The calculation process has been shown in Table S6.

Table S2: Data source of direct energy use coefficients. Year in this table is the time that data be collected.

\begin{tabular}{|c|c|c|c|c|c|}
\hline Life Stage & $1991 \sim 1995$ & 1996 2000 & 2001 2005 & 2006 2010 & $2011 \sim 2016$ \\
\hline Mining & IAI $(1995-1998)^{\mathrm{a}}$ & IAI (2000) & IAI (2005) & IAI (2010) & IAI (2015) \\
\hline Refining & \multicolumn{5}{|l|}{ IAI (1991-2016) } \\
\hline Paste/Anode Production & IAI $(1995-1998)^{\mathrm{a}}$ & IAI (2000) & IAI (2005) & IAI (2010) & IAI (2015) \\
\hline Electrolysis & \multicolumn{5}{|l|}{ IAI (1991-2016) } \\
\hline Ingot Casting & IAI (1995-1998)a & IAI (2000) & IAI (2005) & IAI (2010) & IAI (2015) \\
\hline Rolling & EAA (1998) & $\begin{array}{l}\text { EAA } \\
2002)^{\mathrm{b}}\end{array}$ & EAA (2005) & EAA (2010) & EAA (2015) \\
\hline Extrusion & EAA (1998) & $\begin{array}{l}\text { EAA } \\
2002)^{\mathrm{b}}\end{array}$ & EAA (2005) & EAA (2010) & EAA (2015) \\
\hline Foil & EAA (1998) & $\begin{array}{l}\text { EAA } \\
2002)^{b}\end{array}$ & EAA (2005) & EAA (2010) & EAA (2015) \\
\hline Powder \& Flaked & EAA (1998) & $\begin{array}{l}\text { EAA } \\
2002)^{b}\end{array}$ & EAA (2005) & EAA (2010) & EAA (2015) \\
\hline Collection \& Pre-treating & EAA (1998) & $\begin{array}{l}\text { EAA } \\
2002)^{\mathrm{b}}\end{array}$ & EAA (2005) & $\operatorname{EAA}(2005)^{\mathrm{c}}$ & EAA $(2005)^{c}$ \\
\hline Recycling & EAA $(1998)^{\mathrm{a}}$ & $\begin{array}{l}\text { EAA } \\
2002)^{b}\end{array}$ & EAA (2005) & EAA (2010) & EAA (2015) \\
\hline
\end{tabular}

a. In IAI's 1998 report, data in different production processes are collected during 1995-1998.

b. Coefficients from 1996 to 2000 are the average value of data collected in the year 1998 and 2002 .

c. There are no date collected by EAA after 2005.

d. Assumed to have the same energy use coefficients of extrusion. 
Table S3: Calorific values for types of fuel ${ }^{18}$.

\begin{tabular}{|c|l|l|l|l|l|c|}
\hline Fuel & \multicolumn{1}{|c|}{ Heavy Oil } & Diesel \& LFO & \multicolumn{1}{|c|}{ Gasoline } & Natural Gas & Propane & Coal \\
\hline Calorific value $(\mathrm{TJ} / \mathrm{Gg})$ & $40.4^{\mathrm{a}}$ & 43 & 44.3 & 48 & $47.3^{\mathrm{b}}$ & $26.7^{\mathrm{c}}$ \\
\hline
\end{tabular}
a. Calorific value of residual fuel oil
b. Calorific value of liquefied petroleum gases
c. Calorific value of anthracite

Table S4: Coefficients of energy input in petrol coke and pitch production ${ }^{19}$.

\begin{tabular}{|c|l|l|}
\hline \multicolumn{1}{|c|}{ Process } & \multicolumn{1}{|c|}{ Petrol coke } & \multicolumn{1}{c|}{ Pitch } \\
\hline Energy use coefficient $(\mathrm{MJ} / \mathrm{kg})$ & 4.165 & 0.421 \\
\hline
\end{tabular}

Table S5: Indirect energy input for fuel production ${ }^{3}$.

\begin{tabular}{|c|l|l|l|l|l|l|}
\hline Fuel & Heavy Oil & Diesel \& LFO & Gasoline & Natural Gas & Propane & Coal \\
\hline Energy use coefficient (MJ/MJ delivered) & 0.0305 & 0.0385 & 0.0969 & 0.0292 & $0.0292^{\mathrm{a}}$ & 0.0058 \\
\hline
\end{tabular}

a. Assumed to be the same coefficient of natural gas.

Table S6: Secondary energy use for electricity ${ }^{20}$.

\begin{tabular}{|l|l|l|l|l|l|l|l|l|}
\hline $\begin{array}{c}\text { Electricity } \\
\text { source }\end{array}$ & Hydro & Coal & Oil & $\begin{array}{c}\text { Natural } \\
\text { Gas }\end{array}$ & Nuclear & $\begin{array}{c}\text { Secondary Energy } \\
\text { production } \\
\text { (MJ/MJ delivered) }\end{array}$ & $\begin{array}{c}\text { Transmission } \\
\text { energy loss } \\
\text { (MJ/MJ delivered) }\end{array}$ & $\begin{array}{c}\text { Total secondary } \\
\text { energy } \\
\text { (MJ delivered) }\end{array}$ \\
\hline 1991 & $57 \%$ & $33 \%$ & $1 \%$ & $4 \%$ & $5 \%$ & 0.96 & 0.0950 & 1.0542 \\
\hline 1992 & $57 \%$ & $32 \%$ & $1 \%$ & $5 \%$ & $5 \%$ & 0.95 & 0.0950 & 1.0452 \\
\hline 1993 & $57 \%$ & $30 \%$ & $1 \%$ & $6 \%$ & $5 \%$ & 0.94 & 0.0950 & 1.0320 \\
\hline 1994 & $58 \%$ & $28 \%$ & $1 \%$ & $6 \%$ & $6 \%$ & 0.89 & 0.0950 & 0.9885 \\
\hline 1995 & $53 \%$ & $35 \%$ & $2 \%$ & $6 \%$ & $5 \%$ & 1.06 & 0.0950 & 1.1565 \\
\hline 1996 & $51 \%$ & $37 \%$ & $1 \%$ & $6 \%$ & $5 \%$ & 1.10 & 0.0950 & 1.1905 \\
\hline 1997 & $51 \%$ & $37 \%$ & $0 \%$ & $7 \%$ & $5 \%$ & 1.12 & 0.0950 & 1.2197 \\
\hline 1998 & $48 \%$ & $39 \%$ & $0 \%$ & $8 \%$ & $5 \%$ & 1.17 & 0.0950 & 1.2687 \\
\hline 1999 & $48 \%$ & $39 \%$ & $1 \%$ & $7 \%$ & $6 \%$ & 1.17 & 0.0950 & 1.2628 \\
\hline 2000 & $46 \%$ & $40 \%$ & $1 \%$ & $8 \%$ & $5 \%$ & 1.21 & 0.0950 & 1.3061 \\
\hline 2001 & $43 \%$ & $44 \%$ & $1 \%$ & $8 \%$ & $4 \%$ & 1.33 & 0.0950 & 1.4210 \\
\hline 2002 & $42 \%$ & $46 \%$ & $0 \%$ & $7 \%$ & $4 \%$ & 1.37 & 0.0950 & 0.0950 \\
\hline 2003 & $40 \%$ & $49 \%$ & $0 \%$ & $7 \%$ & $4 \%$ & 1.43 & 0.0950 & 1.4616 \\
\hline 2004 & $41 \%$ & $48 \%$ & $1 \%$ & $7 \%$ & $4 \%$ & 1.41 & 1.5265 \\
\hline
\end{tabular}




\begin{tabular}{|l|l|l|l|l|l|l|l|l|}
\hline 2005 & $45 \%$ & $44 \%$ & $1 \%$ & $7 \%$ & $4 \%$ & 1.29 & 0.0950 & 1.3802 \\
\hline 2006 & $42 \%$ & $48 \%$ & $1 \%$ & $6 \%$ & $3 \%$ & 1.38 & 0.0950 & 1.4789 \\
\hline 2007 & $42 \%$ & $49 \%$ & $0 \%$ & $6 \%$ & $3 \%$ & 1.41 & 0.0950 & 1.5093 \\
\hline 2008 & $40 \%$ & $50 \%$ & $0 \%$ & $7 \%$ & $3 \%$ & 1.46 & 0.0950 & 1.5534 \\
\hline 2009 & $38 \%$ & $51 \%$ & $0 \%$ & $8 \%$ & $2 \%$ & 1.50 & 0.0950 & 1.5958 \\
\hline 2010 & $41 \%$ & $51 \%$ & $0 \%$ & $5 \%$ & $2 \%$ & 1.45 & 0.0950 & 0.0950 \\
\hline 2011 & $39 \%$ & $53 \%$ & $0 \%$ & $7 \%$ & $1 \%$ & 1.53 & 0.0950 & 1.5418 \\
\hline 2012 & $38 \%$ & $53 \%$ & $0 \%$ & $8 \%$ & $2 \%$ & 1.54 & 0.0950 & 1.6288 \\
\hline 2013 & $36 \%$ & $54 \%$ & $0 \%$ & $8 \%$ & $1 \%$ & 1.59 & 0.0950 & 1.6390 \\
\hline 2014 & $31 \%$ & $58 \%$ & $0 \%$ & $10 \%$ & $1 \%$ & 1.72 & 0.0950 & 1.8110 \\
\hline 2015 & $30 \%$ & $59 \%$ & $0 \%$ & $9 \%$ & $2 \%$ & 1.72 & 0.0950 & 1.8182 \\
\hline 2016 & $28 \%$ & $61 \%$ & $0 \%$ & $10 \%$ & $1 \%$ & 1.80 & 1.8930 \\
\hline
\end{tabular}

\subsubsection{GHG emissions}

Both IAI and EAA don't report GHG emissions data. Direct GHG emissions coefficients are calculated by direct energy use coefficients. IAI have provided technical guidance ${ }^{21}$ and tools ${ }^{22}$ to support aluminum producers and researchers quantifying GHG emissions. We use them to estimate GHG emissions. Some estimated parameter and source can be seen in Table S7-S10.

Indirect GHG emissions coefficients from electricity production in the period 1991-2016 are estimated by IAI global power mix data. These data are shown in Table S11. Global perfluorocarbon emissions intensity during 1991 to 2016 have been reported by IAI, which are used immediately.

Table S7: Direct GHG emissions intensity data ${ }^{23}$.

\begin{tabular}{|c|l|l|l|l|l|l|}
\hline Fuel & \multicolumn{1}{|c|}{ Heavy Oil } & Diesel \& LFO & Gasoline & Natural Gas & Propane & Coal \\
\hline $\begin{array}{l}\text { Carbon emissions coefficient } \\
(\mathrm{kg} \mathrm{CO} 2 \mathrm{e} / \mathrm{kg})\end{array}$ & 3 & 3 & 2 & 2.79 & 3 & 2.5 \\
\hline
\end{tabular}

Table S8: Emission factors for calculating process $\mathrm{CO}_{2}$ emissions from petrol coke and pitch productiona.

\begin{tabular}{|c|l|l|}
\hline \multicolumn{1}{|c|}{ Process } & \multicolumn{1}{|c|}{ Petrol coke production } & \multicolumn{1}{c|}{ Pitch production } \\
\hline Emission factor $\left(\mathrm{kg} \mathrm{CO}_{2} / \mathrm{kg}\right)$ & 0.2472 & 0.0258 \\
\hline
\end{tabular}

a. These data are calculated by fuel use in production. Emission coefficients of fuels are from IPCC (2006). 
Table S9: Emission factors for calculating process $\mathrm{CO}_{2}$ emissions from Paste/Anode consumption ${ }^{22}$.

\begin{tabular}{|c|l|l|}
\hline \multicolumn{1}{|c|}{ Process } & \multicolumn{1}{|c|}{ Søderberg (Paste consumption) } & Prebake (Anode consumption) \\
\hline Emission factor $\left(\mathrm{kg} \mathrm{CO}_{2} / \mathrm{t} \mathrm{Al}\right)$ & 1700 & 1600 \\
\hline
\end{tabular}

Table S10: Indirect emissions from fuel production ${ }^{3}$.

\begin{tabular}{|c|l|l|l|l|l|l|}
\hline Fuel & Heavy Oil & Diesel \& LFO & Gasoline & Natural Gas & Propane & Coal \\
\hline Emission coefficient $\left(\mathrm{kg} \mathrm{CO}_{2} / \mathrm{MJ}\right.$ delivered) & 0.009 & 0.015 & 0.015 & 0.014 & $0.014^{\mathrm{a}}$ & 0.005 \\
\hline
\end{tabular}

a. Assumed to be the same coefficient of natural gas.

Table S11: GHG emissions coefficients for electricity production.

\begin{tabular}{|c|l|l|l|l|l|l|l|l|l|l|l|l|l|}
\hline Year & 1991 & 1992 & 1993 & 1994 & 1995 & 1996 & 1997 & 1998 & 1999 & 2000 & 2001 & 2002 & 2003 \\
\hline $\begin{array}{c}\text { Coefficie } \\
\text { nt }\end{array}$ & 0.354 & 0.350 & 0.343 & 0.328 & 0.384 & 0.394 & 0.402 & 0.416 & 0.415 & 0.428 & 0.465 & 0.479 & 0.501 \\
& 2 & 5 & 6 & 5 & 5 & 2 & 2 & 9 & 6 & 5 & 3 \\
\hline Year & 2004 & 2005 & 2006 & 2007 & 2008 & 2009 & 2010 & 2011 & 2012 & 2013 & 2014 & 2015 & 2016 \\
\hline $\begin{array}{c}\text { Coefficie } \\
\text { nt }\end{array}$ & 0.493 & 0.454 & 0.487 & 0.497 & 0.509 & 0.520 & 0.510 & 0.533 & 0.536 & 0.548 & 0.587 & 0.590 & 0.614 \\
4 & 6 & 6 & 5 & 7 & 4 & 3 & 5 & 0 & 1 & 8 & 4 \\
\hline
\end{tabular}

\subsubsection{Converting process incremental data into CTP data}

Section 4.2 and 4.3 illustrate the process incremental energy use (or GHG emissions) intensity of raw materials and semis. We should convert these data into CTP data. Factors we use are shown in Table S12.

Table S12: Factors to convert process incremental data into CTP data ${ }^{12-16}$.

\begin{tabular}{|l|l|l|l|l|l|}
\hline \multicolumn{1}{|c|}{ Conversion factor (Input/Output) } & $1991 \sim 1995$ & $1996 \sim 2000$ & $2001 \sim 2005$ & $2006 \sim 2010$ & $2011 \sim 2016$ \\
\hline Bauxite/Ingot-unalloyed & 5.0880 & 5.1680 & 5.2680 & 5.5710 & 5.5000 \\
\hline Alumina/Ingot-unalloyed & 1.9280 & 1.9250 & 1.9230 & 1.9340 & 2.0000 \\
\hline Anode/Ingot-unalloyed & 0.3862 & 0.3844 & 0.3130 & 0.3916 & 0.4399 \\
\hline Paste/Ingot-unalloyed & 0.0568 & 0.0566 & 0.1220 & 0.0484 & 0.0232 \\
\hline Electrolysis/Ingot-unalloyed & 1.0000 & 1.0000 & 1.0000 & 1.0000 & 1.0000 \\
\hline Aluminum waste \& scrap/Secondary aluminum & 1.0140 & 1.0140 & 1.0090 & 1.0410 & 1.0190 \\
\hline Ingot-unalloyed/Extrusion & 0.8850 & 1.0130 & 1.0080 & 1.0000 & 1.0030 \\
\hline Secondary aluminum/Extrusion & 0.5590 & 0.3240 & 0.3240 & 0.3230 & 0.2910 \\
\hline Ingot-unalloyed/Rolling & 1.0200 & 1.0120 & 1.0040 & 1.0040 & 1.0040 \\
\hline Secondary aluminum/Rolling & 0.3830 & 0.3830 & 0.3830 & 0.4060 & 0.3470 \\
\hline Ingot-unalloyed/Foil & 1.0320 & 1.0320 & 1.0070 & 1.0100 & 1.0070 \\
\hline
\end{tabular}




\begin{tabular}{|l|l|l|l|l|l|}
\hline Secondary aluminum/Foil & 0.5950 & 0.5950 & 0.5950 & 0.3900 & 0.1550 \\
\hline Ingot-unalloyed/Powder and flake & 0.8850 & 1.0130 & 1.0080 & 1.0410 & 1.0030 \\
\hline Secondary aluminum/Powder and flake & 0.5590 & 0.3240 & 0.3240 & 0.3230 & 0.2910 \\
\hline
\end{tabular}

\subsection{Estimating Method of Incremental Energy Use and GHG Emissions for Manufacturing Process}

Input-Output Life Cycle Assessment (IO-LCA) is used to calculating incremental energy use (GHG emissions) intensity (indicated by $E I_{\text {Finished } A C P}^{I n c}$ and $G I_{\text {Finished } A C P}^{I n c}$ ) intensity for manufacturing process of each finished ACP, which is calculated by direct energy use and GHG emissions intensity (indicated by $E I_{\text {Industry }}^{\text {dir }}$ and $G I_{\text {Industry }}^{\text {dir }}$ ) for industries which finished ACP belongs to. So, the key is to estimate direct energy use and GHG emissions intensity of industries which ACPs belongs to.

Direct energy use (GHG emissions) intensity of industry is calculated by IO tables and their satellite. Figure S3 shows the structure of an input-output table. According to the environmental input-output analysis developed by Leontief ${ }^{24}$, direct energy use and GHG emissions intensity for industry $m$ in the year $j$ can be obtained as follows:

$$
\begin{aligned}
& E I_{\text {Industry }_{m, j}}^{\text {dir }}=T E_{m, j} / X_{j} \\
& G I_{\text {Industry }_{m, j}}^{\text {dir }}=T G_{m, j} / X_{j}
\end{aligned}
$$

where $A$ is the technical coefficients matrix in the year $j, T E_{m, j}$ and $T G_{m, j}$ are the total energy use and GHG emissions for industry $m$ in the year $j$; total output is denoted by $X$ which contains domestic consumption and export.

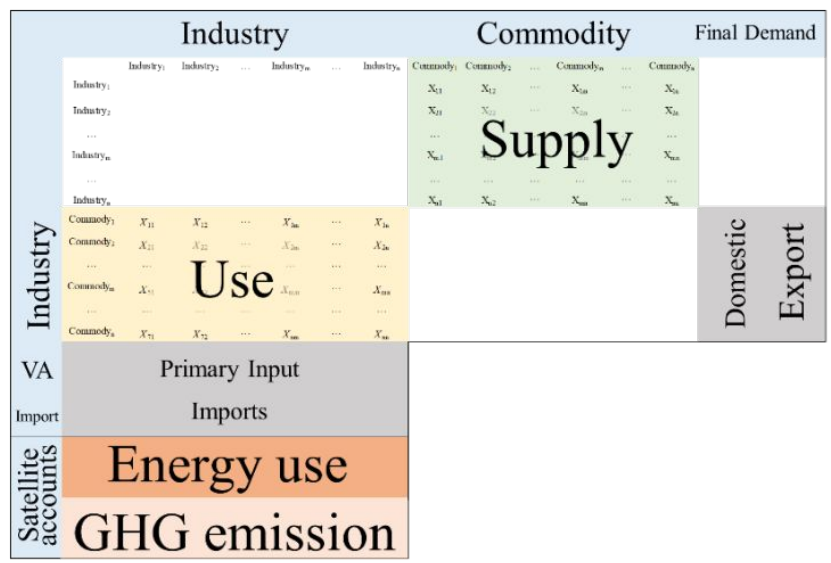

Figure S3: Basic structure of an economic input-output table. 
There are four countries involved in this study, US, China, Japan, and Australia, which publish IO tables every few years. And based on these official IO tables, Eora database has developed timeseries of environmentally extended IO tables for the four countries from 1990 to 2015. Except China, other three countries' IO table have very detailed sector category (more than 300 sectors). So, we use these three countries' environmentally extended IO tables in Eora database to calculate incremental energy use (GHG emissions) intensity in each finished ACP' manufacturing process. Eora database didn't publish IO table for the year 2016, so we use the IO tables in 2015 to replace.

The first step is locating finished ACPs into different sectors of the three countries' IO table. According to some convert files provided by these three countries ${ }^{25-28}$, the relationship between finished ACPs and IO table sectors can be seen in table S13. And then, based on IO tables in Eora database and equation 15 and 16, each industry's direct energy use (GHG emissions) intensity for the three countries can be calculated.

Incremental energy use (GHG emissions) intensity for finished ACPs' manufacturing processes are calculated by each country's export price and industry's direct energy use (GHG emissions) intensity (Equation 10 and 11). However, due to US, Japan and Australia have very different economic structure and technical condition, environmental coefficients about some finished ACPs in the three countries are quite different. Hence, we adopt the average value. 
Table S13: The conversion table between finished ACPs and IO sectors of US, Japan, and Australia.

\begin{tabular}{|c|c|c|c|c|}
\hline SITC1 & Short Description & US IOT & Japan IOT & Australia IOT \\
\hline 7114 & Aircraft incl jet propulsion engines & Aircraft engine and engine parts manufacturing & Aircrafts & Aircraft \\
\hline 7341 & Aircraft, heavier than air & Aircraft manufacturing & Aircrafts & Aircraft \\
\hline 7349 & Parts of aircraft,balloons airships & Other aircraft parts and auxiliary equipment manufacturing & Aircraft & Aircraft \\
\hline 89999 & Catapults and sim.aircraft launching gear,etc. & Guided missile and space vehicle manufacturing & Aircrafts & Aircraft \\
\hline 7351 & Warships of all kinds & Ship building and repairing & Ships (except steel ships) & Ships and boats \\
\hline 7353 & Ships and boats, other than warships & Boat building & Ships (except steel ships) & Ships and boats \\
\hline 7359 & Special purpose ships and boats & Ship building and repairing & Ships (except steel ships) & Ships and boats \\
\hline 71966 & Railway \& tramway track fixtures $\&$ fittings & Railroad rolling stock manufacturing & Rolling stock & Railway equipment \\
\hline 7311 & Railway locomotives steam and tenders & Railroad rolling stock manufacturing & Rolling stock & Railway equipment \\
\hline 7312 & Electric railway locomotives, not self generat. & Railroad rolling stock manufacturing & Rolling stock & Railway equipment \\
\hline 7313 & Railway locomotives, not steam or electric & Railroad rolling stock manufacturing & Rolling stock & Railway equipment \\
\hline 7314 & Mechanically propelled railway and tramway cars & Railroad rolling stock manufacturing & Rolling stock & Railway equipment \\
\hline 7315 & Rail \& tram passenger cars not mech propelled & Railroad rolling stock manufacturing & Rolling stock & Railway equipment \\
\hline 7316 & Rail.\&tram.freight cars,not mechanically propd. & Railroad rolling stock manufacturing & Rolling stock & Railway equipment \\
\hline 7317 & Parts of railway locomotives \& rolling stock & Railroad rolling stock manufacturing & Rolling stock & Railway equipment \\
\hline 7321 & Passenger motor cars, other than buses & Automobile manufacturing & Passenger motor cars & Finished cars \\
\hline 7322 & Buses, including trolleybuses & Heavy duty truck manufacturing & Passenger motor cars & Finished cars \\
\hline 7323 & Lorries and trucks, including ambulances, etc. & Heavy duty truck manufacturing & Passenger motor cars & Trucks \\
\hline 7324 & Special purpose lorries, trucks and vans & Heavy duty truck manufacturing & Passenger motor cars & Trucks \\
\hline 7325 & Road tractors for tractor trailer combinations & Heavy duty truck manufacturing & Passenger motor cars & Trucks \\
\hline 7326 & Chassis with engs. Mntd. For vehicles of 732.1 & Motor Vehicle Body Manufacturing & Motor vehicle bodies & Motor vehicle parts \\
\hline 7327 & Other chassis with engines mounted & Motor Vehicle Body Manufacturing & Motor vehicle bodies & Motor vehicle parts \\
\hline 7328 & Bodies \& parts motor vehicles ex motorcycles & Motor vehicle parts manufacturing & $\begin{array}{l}\text { Motor vehicle parts and } \\
\text { accessories }\end{array}$ & Motor vehicle parts \\
\hline 7329 & Motorcycles, motorized cycles and their parts & Motorcycle, bicycle, and parts manufacturing & Two-wheel motor vehicles & Motor vehicle parts \\
\hline 7331 & Bicycles \& other cycles, not motorized, \& parts & Motorcycle, bicycle, and parts manufacturing & Bicycles & Finished cars \\
\hline 7333 & Trailers \& oth vehicles not motorized, \& parts & Truck trailer manufacturing & Other transport equipment & Motor vehicle parts \\
\hline 7334 & Invalid carriages & Motorcycle, bicycle, and parts manufacturing & Bicycles & Finished cars \\
\hline 7113 & Steam engines and steam turbines & Turbine and turbine generator set units manufacturing & Pumps and compressors & Pumps \\
\hline 7115 & Internal combustion engines, not for aircraft & Motor vehicle parts manufacturing & $\begin{array}{l}\text { Internal combustion engines } \\
\text { for vessels }\end{array}$ & $\begin{array}{l}\text { Industrial machinery and } \\
\text { equipment }\end{array}$ \\
\hline 6324 & Builders woodwork \& prefab. Buildings of wood & Wood windows and doors and millwork & Wooden fixtures & Prefabricated buildings \\
\hline 6912 & Fin.structural parts \& structures of aluminium & Plate work and fabricated structural product manufacturing & $\begin{array}{l}\text { Aluminum (inc. regenerated } \\
\text { aluminum) }\end{array}$ & $\begin{array}{l}\text { Fabricated metal } \\
\text { products }\end{array}$ \\
\hline 69313 & Wire,cables,ropes etc.not insulated,aluminium & Spring and wire product manufacturing & Electric wires and cables & $\begin{array}{l}\text { Fabricated metal } \\
\text { products }\end{array}$ \\
\hline
\end{tabular}




\begin{tabular}{|c|c|c|c|c|}
\hline 69882 & Flexible tubing and piping of base metal & Fabricated Pipe and Pipe Fitting Manufacturing & $\begin{array}{l}\text { Plumber's supplies, powder } \\
\text { metallurgy products and } \\
\text { tools }\end{array}$ & $\begin{array}{l}\text { Fabricated metal } \\
\text { products }\end{array}$ \\
\hline 69884 & Bells (non electric), of base metal & All other miscellaneous manufacturing & Other metal products & $\begin{array}{l}\text { Fabricated metal } \\
\text { products }\end{array}$ \\
\hline 69886 & Name plates,sign plates, etc.of base metal & Sign manufacturing & Other metal products & $\begin{array}{l}\text { Fabricated metal } \\
\text { products }\end{array}$ \\
\hline 7111 & Steam generating boilers & Power boiler and heat exchanger manufacturing & Boilers & $\begin{array}{l}\text { Industrial machinery and } \\
\text { equipment }\end{array}$ \\
\hline 7112 & Boiler house plant & Power boiler and heat exchanger manufacturing & Boilers & $\begin{array}{l}\text { Industrial machinery and } \\
\text { equipment }\end{array}$ \\
\hline 7121 & Agricultural machinery for cultivating the soil & Farm machinery and equipment manufacturing & $\begin{array}{l}\text { Machinery for agricultural } \\
\text { use }\end{array}$ & $\begin{array}{l}\text { Tillage, seeding, planting } \\
\text { and fertilising equipment }\end{array}$ \\
\hline 7122 & Agricultural machinery for harvesting, threshing & Farm machinery and equipment manufacturing & $\begin{array}{l}\text { Machinery for agricultural } \\
\text { use }\end{array}$ & $\begin{array}{l}\text { Harvesting, haymaking } \\
\text { and silage making } \\
\text { equipment }\end{array}$ \\
\hline 7123 & Milking machines,cream separators, dairy farm eq & Farm machinery and equipment manufacturing & Food processing machinery & $\begin{array}{l}\text { Industrial machinery and } \\
\text { equipment }\end{array}$ \\
\hline 7125 & Tractors, other than road tractors & Farm machinery and equipment manufacturing & $\begin{array}{l}\text { Machinery for agricultural } \\
\text { use }\end{array}$ & Agricultural tractors \\
\hline 7129 & Agricultural machinery and appliances, nes & Farm machinery and equipment manufacturing & Food processing machinery & $\begin{array}{l}\text { Industrial machinery and } \\
\text { equipment }\end{array}$ \\
\hline 7151 & Machine tools for working metals & Metal cutting and forming machine tool manufacturing & Metal processing machinery & $\begin{array}{l}\text { Industrial machinery and } \\
\text { equipment }\end{array}$ \\
\hline 7152 & Other metalworking machinery & Other industrial machinery manufacturing & Metal processing machinery & $\begin{array}{l}\text { Industrial machinery and } \\
\text { equipment }\end{array}$ \\
\hline 7171 & Textile machinery & Other industrial machinery manufacturing & Textile machinery & $\begin{array}{l}\text { Industrial machinery and } \\
\text { equipment }\end{array}$ \\
\hline 7172 & Machinery ex.sewing mach. For working hides etc & Other general purpose machinery manufacturing & Textile machinery & $\begin{array}{l}\text { Industrial machinery and } \\
\text { equipment }\end{array}$ \\
\hline 7173 & Sewing machines & Other general purpose machinery manufacturing & Textile machinery & $\begin{array}{l}\text { Industrial machinery and } \\
\text { equipment }\end{array}$ \\
\hline 7181 & Paper mill and pulp mill machinery, etc. & Other industrial machinery manufacturing & $\begin{array}{l}\text { Other special machinery for } \\
\text { industrial use }\end{array}$ & $\begin{array}{l}\text { Industrial machinery and } \\
\text { equipment }\end{array}$ \\
\hline 7182 & Printing and bookbinding machinery & Other industrial machinery manufacturing & $\begin{array}{l}\text { Other special machinery for } \\
\text { industrial use }\end{array}$ & $\begin{array}{l}\text { Industrial machinery and } \\
\text { equipment }\end{array}$ \\
\hline 7183 & Food processing machines, excluding domestic & Other industrial machinery manufacturing & Food processing machinery & $\begin{array}{l}\text { Industrial machinery and } \\
\text { equipment }\end{array}$ \\
\hline 7184 & Construction and mining machinery, nes & Construction machinery manufacturing & $\begin{array}{l}\text { Machinery and equipment } \\
\text { for construction and mining }\end{array}$ & Construction machinery \\
\hline 7185 & Mineral crushing etc. \& glass working machinery & Mining and Oil and Gas Field Machinery Manufacturing & $\begin{array}{l}\text { Machinery and equipment } \\
\text { for construction and mining }\end{array}$ & $\begin{array}{l}\text { Machinery for crushing, } \\
\text { grinding, mixing }\end{array}$ \\
\hline
\end{tabular}




\begin{tabular}{|c|c|c|c|c|}
\hline 7191 & Heating and cooling equipment & Air conditioning, refrigeration, and warm air heating equipment manufacturing & $\begin{array}{l}\text { Refrigerators and air } \\
\text { conditioning apparatus }\end{array}$ & Air conditioning \\
\hline 7192 & Pumps and centrifuges & Pump and pumping equipment manufacturing & Pumps and compressors & Pumps \\
\hline 7193 & Mechanical handling equipment & Material handling equipment manufacturing & Conveyors & $\begin{array}{l}\text { Hoists, cranes, lifting } \\
\text { and loading machinery }\end{array}$ \\
\hline 7195 & Powered tools, nes & Power-driven handtool manufacturing & Metal machine tools & $\begin{array}{l}\text { Industrial machinery and } \\
\text { equipment }\end{array}$ \\
\hline 71961 & Calendering mach \& similar rolling machines & Rolling mill and other metalworking machinery manufacturing & $\begin{array}{l}\text { Other general industrial } \\
\text { machinery and equipment }\end{array}$ & $\begin{array}{l}\text { Industrial machinery and } \\
\text { equipment }\end{array}$ \\
\hline 71963 & Weighing machinery and weights therefor & Other general purpose machinery manufacturing & $\begin{array}{l}\text { Other general industrial } \\
\text { machinery and equipment }\end{array}$ & $\begin{array}{l}\text { Industrial machinery and } \\
\text { equipment }\end{array}$ \\
\hline 71964 & Spraying machinery & Other general purpose machinery manufacturing & $\begin{array}{l}\text { Other general industrial } \\
\text { machinery and equipment }\end{array}$ & $\begin{array}{l}\text { Industrial machinery and } \\
\text { equipment }\end{array}$ \\
\hline 71965 & Automatic vending machines & Other general purpose machinery manufacturing & $\begin{array}{l}\text { Other general industrial } \\
\text { machinery and equipment }\end{array}$ & $\begin{array}{l}\text { Industrial machinery and } \\
\text { equipment }\end{array}$ \\
\hline 7197 & Ball, roller or needle roller bearings & Ball and roller bearing manufacturing & Bearings & $\begin{array}{l}\text { Industrial machinery and } \\
\text { equipment }\end{array}$ \\
\hline 7198 & Machinery and mechanical appliances, nes & Other Industrial Machinery Manufacturing & $\begin{array}{l}\text { Other special machinery for } \\
\text { industrial use }\end{array}$ & $\begin{array}{l}\text { Industrial machinery and } \\
\text { equipment }\end{array}$ \\
\hline 7199 & Parts and accessories of machinery, nes & Other Industrial Machinery Manufacturing & $\begin{array}{l}\text { Other general machines and } \\
\text { parts }\end{array}$ & $\begin{array}{l}\text { Industrial machinery and } \\
\text { equipment }\end{array}$ \\
\hline 7295 & Electrical measuring \& controlling instruments & Industrial process variable instruments manufacturing & $\begin{array}{l}\text { Analytical instruments, } \\
\text { testing machine, measuring } \\
\text { instruments }\end{array}$ & Surgical and medical \\
\hline 8613 & Binoculars, microscopes \& other optical instrum & Optical instrument and lens manufacturing & $\begin{array}{l}\text { Other photographic and } \\
\text { optical instruments }\end{array}$ & $\begin{array}{l}\text { Photographic and } \\
\text { scientific equipment }\end{array}$ \\
\hline 8617 & Medical instruments, nes & Surgical and medical instrument manufacturing & Medical instruments & Surgical and medical \\
\hline 8618 & Meters and counters, non electric & Watch, clock, and other measuring and controlling device manufacturing & $\begin{array}{l}\text { Analytical instruments, } \\
\text { testing machine, measuring } \\
\text { instruments }\end{array}$ & $\begin{array}{l}\text { Photographic and } \\
\text { scientific equipment }\end{array}$ \\
\hline 8619 & Measuring,controlling \& scientific instruments & Analytical laboratory instrument manufacturing & $\begin{array}{l}\text { Professional and scientific } \\
\text { instruments }\end{array}$ & $\begin{array}{l}\text { Photographic and } \\
\text { scientific equipment }\end{array}$ \\
\hline 69723 & Domestic utensils of aluminium & Cutlery, utensil, pot, and pan manufacturing & Other metal products & $\begin{array}{l}\text { Fabricated metal } \\
\text { products }\end{array}$ \\
\hline 69792 & Imdoor ornaments of base metals,n.e.s & Ornamental and architectural metal products manufacturing & Other metal products & $\begin{array}{l}\text { Fabricated metal } \\
\text { products }\end{array}$ \\
\hline 6981 & Locksmiths wares & Hardware manufacturing & Other metal products & $\begin{array}{l}\text { Fabricated metal } \\
\text { products }\end{array}$ \\
\hline 6982 & Safes,strong rooms, strong room fittings etc. & Hardware manufacturing & Other metal products & $\begin{array}{l}\text { Fabricated metal } \\
\text { products }\end{array}$ \\
\hline 7141 & Typewriters and cheque writing machines & Vending, commercial, industrial, and office machinery manufacturing & Copy machine & Electronic equipment \\
\hline
\end{tabular}




\begin{tabular}{|c|c|c|c|c|}
\hline 7142 & Calculating \& accounting machines etc & Vending, commercial, industrial, and office machinery manufacturing & $\begin{array}{l}\text { Electronic computing } \\
\text { equipment (except personal } \\
\text { computers) }\end{array}$ & Electronic equipment \\
\hline 7143 & Statistical machines cards or tapes & Vending, commercial, industrial, and office machinery manufacturing & $\begin{array}{l}\text { Electronic computing } \\
\text { equipment (accessory } \\
\text { equipment) }\end{array}$ & Electronic equipment \\
\hline 7149 & Office machines, nes & Vending, commercial, industrial, and office machinery manufacturing & Other office machines & Electronic equipment \\
\hline 71941 & Domestic food processing appliances,non elect & Other fabricated metal manufacturing & Other metal products & $\begin{array}{l}\text { Fabricated metal } \\
\text { products }\end{array}$ \\
\hline 71942 & Domestic refrigerators, non electrical & Other fabricated metal manufacturing & Other metal products & Air conditioning \\
\hline 71943 & Domestic water heaters, non electrical & Heating equipment (except warm air furnaces) manufacturing & $\begin{array}{l}\text { Gas and oil appliances and } \\
\text { heating and cooking } \\
\text { apparatus }\end{array}$ & $\begin{array}{l}\text { Water heater, non- } \\
\text { electric }\end{array}$ \\
\hline 71962 & Mach.for cleaning or filling containers & Packaging machinery manufacturing & $\begin{array}{l}\text { Other electrical devices and } \\
\text { parts }\end{array}$ & Electrical equipment \\
\hline 7241 & Television broadcast receivers & Broadcast and wireless communications equipment & Radio and television sets & Electrical equipment \\
\hline 7242 & Radio broadcast receivers & Broadcast and wireless communications equipment & Radio and television sets & Electrical equipment \\
\hline 7249 & Telecommunications equipment nes & Telephone Apparatus Manufacturing & Cellular phones & Electronic equipment \\
\hline 72501 & Domestic refrigerators, electrical & Household refrigerator and home freezer manufacturing & $\begin{array}{l}\text { Household electric } \\
\text { appliances (except air- } \\
\text { conditioners) }\end{array}$ & Domestic refrigerators \\
\hline 72502 & Domestic washing machines whether or not elec. & Household laundry equipment manufacturing & $\begin{array}{l}\text { Household electric } \\
\text { appliances (except air- } \\
\text { conditioners) }\end{array}$ & $\begin{array}{l}\text { Clothes washing } \\
\text { machines }\end{array}$ \\
\hline 72503 & Electro mechanical domestic appliances nes & Small electrical appliance manufacturing & $\begin{array}{l}\text { Household electric } \\
\text { appliances (except air- } \\
\text { conditioners) }\end{array}$ & Household appliances \\
\hline 72504 & Electric shavers \& hair clippers & Small electrical appliance manufacturing & $\begin{array}{l}\text { Household electric } \\
\text { appliances (except air- } \\
\text { conditioners) }\end{array}$ & Household appliances \\
\hline 72505 & Electric space heating equipment etc. & Household Cooking Appliance Manufacturing & $\begin{array}{l}\text { Household electric } \\
\text { appliances (except air- } \\
\text { conditioners) }\end{array}$ & Space heaters, electric \\
\hline 7261 & Electro medical apparatus & Electromedical and electrotherapeutic apparatus manufacturing & Medical instruments & Surgical and medical \\
\hline 7262 & $\mathrm{X}$ ray apparatus & Irradiation apparatus manufacturing & Medical instruments & Surgical and medical \\
\hline 7291 & Batteries and accumulators & Storage battery manufacturing & Batteries & Electrical equipment \\
\hline 7292 & Electric lamps & Electric lamp bulb and part manufacturing & $\begin{array}{l}\text { Electric lighting fixtures } \\
\text { and apparatus }\end{array}$ & Electrical equipment \\
\hline 7293 & Thermionic valves and tubes, transistors, etc. & Electron tube manufacturing & Electron tubes & Electronic equipment \\
\hline 7294 & Automotive electrical equipment & Motor vehicle parts manufacturing & $\begin{array}{l}\text { Electrical equipment for } \\
\text { internal combustion engines }\end{array}$ & Electrical equipment \\
\hline 7296 & Electro mechanical hand tools & Power-Driven Handtool Manufacturing & Metal machine tools & $\begin{array}{l}\text { Industrial machinery and } \\
\text { equipment }\end{array}$ \\
\hline
\end{tabular}




\begin{tabular}{|c|c|c|c|c|}
\hline 7297 & Electron and proton accelerators & All other miscellaneous electrical equipment and component manufacturing & $\begin{array}{l}\text { Other electrical devices and } \\
\text { parts }\end{array}$ & Electrical equipment \\
\hline 7299 & Electrical machinery and apparatus, nes & Other general purpose machinery manufacturing & $\begin{array}{l}\text { Other electronic } \\
\text { components }\end{array}$ & Electronic equipment \\
\hline 8124 & Lighting fixtures and fittings and parts & Lighting fixture manufacturing & $\begin{array}{l}\text { Electric lighting fixtures } \\
\text { and apparatus }\end{array}$ & Electrical equipment \\
\hline 8210 & Furniture & Metal and other household furniture (except wood) manufacturing1 & $\begin{array}{l}\text { Metallic furniture and } \\
\text { fixture }\end{array}$ & Furniture \\
\hline 8413 & Apparel and clothing accessories of leather & Leather and hide tanning and finishing & Woven fabric apparel & Clothing \\
\hline 8612 & Spectacles and spectacle frames & Ophthalmic goods manufacturing & $\begin{array}{l}\text { Other photographic and } \\
\text { optical instruments }\end{array}$ & $\begin{array}{l}\text { Spectacles and } \\
\text { sunglasses }\end{array}$ \\
\hline 8614 & Photographic cameras and flashlight apparatus & Photographic and photocopying equipment manufacturing & Camera & $\begin{array}{l}\text { Photographic and } \\
\text { scientific equipment }\end{array}$ \\
\hline 8615 & Cine. Cameras, projectors, sound recorders etc. & Audio and video equipment manufacturing & $\begin{array}{l}\text { Video recording and } \\
\text { playback equipment }\end{array}$ & Electronic equipment \\
\hline 8616 & Photographic \& cinematographic equipment nes & Photographic and photocopying equipment manufacturing & $\begin{array}{l}\text { Other photographic and } \\
\text { optical instruments }\end{array}$ & Electronic equipment \\
\hline 8641 & Watches, watch movements and cases & Watch, clock, and other measuring and controlling device manufacturing & Watches and clocks & $\begin{array}{l}\text { Photographic and } \\
\text { scientific equipment }\end{array}$ \\
\hline 8642 & Clocks, clock movements and parts & Watch, clock, and other measuring and controlling device manufacturing & Watches and clocks & $\begin{array}{l}\text { Photographic and } \\
\text { scientific equipment }\end{array}$ \\
\hline 8911 & Phonographs, tape \& other sound recorders etc. & Audio and Video Equipment Manufacturing & Magnetic tapes and discs & Electronic equipment \\
\hline 8914 & Pianos and other string musical instruments & Musical instrument manufacturing & Musical instruments & $\begin{array}{l}\text { Miscellaneous } \\
\text { manufacturing }\end{array}$ \\
\hline 8918 & Musical instruments, nes & Musical instrument manufacturing & Musical instruments & $\begin{array}{l}\text { Miscellaneous } \\
\text { manufacturing }\end{array}$ \\
\hline 8919 & Parts and accessories of musical instruments & Musical instrument manufacturing & Musical instruments & $\begin{array}{l}\text { Miscellaneous } \\
\text { manufacturing }\end{array}$ \\
\hline 8941 & Baby and invalid carriages not motorized & All Other Transportation Equipment Manufacturing & Bicycles & $\begin{array}{l}\text { Miscellaneous } \\
\text { manufacturing }\end{array}$ \\
\hline 8942 & Childrens toys, indoor games, etc. & Doll, toy, and game manufacturing & Toys and games & $\begin{array}{l}\text { Miscellaneous } \\
\text { manufacturing }\end{array}$ \\
\hline 8944 & Other sporting goods & Sporting and athletic goods manufacturing & Sporting and athletic goods & $\begin{array}{l}\text { Miscellaneous } \\
\text { manufacturing }\end{array}$ \\
\hline 8945 & Fairground amusements, etc. & Sporting and athletic goods manufacturing & $\begin{array}{l}\text { Miscellaneous } \\
\text { manufacturing products }\end{array}$ & $\begin{array}{l}\text { Miscellaneous } \\
\text { manufacturing }\end{array}$ \\
\hline 8951 & Office and stationery supplies of base metals & Office supplies (except paper) manufacturing & Other metal products & $\begin{array}{l}\text { Fabricated metal } \\
\text { products }\end{array}$ \\
\hline 7116 & Gas turbines, other than for aircraft & Turbine and turbine generator set units manufacturing & Turbines & $\begin{array}{l}\text { Industrial machinery and } \\
\text { equipment }\end{array}$ \\
\hline 7117 & Nuclear reactors & Power Boiler and Heat Exchanger Manufacturing & Boilers & $\begin{array}{l}\text { Industrial machinery and } \\
\text { equipment }\end{array}$ \\
\hline
\end{tabular}




\begin{tabular}{|c|c|c|c|c|}
\hline 7118 & Engines, nes & Other industrial machinery manufacturing & Engines & $\begin{array}{l}\text { Industrial machinery and } \\
\text { equipment }\end{array}$ \\
\hline 7221 & Electric power machinery & Motor and Generator Manufacturing & $\begin{array}{l}\text { Other industrial heavy } \\
\text { electrical equipment }\end{array}$ & Electrical equipment \\
\hline 7222 & Apparatus for electrical circuits & Printed circuit assembly (electronic assembly) manufacturing & Integrated circuits & Electronic equipment \\
\hline 7231 & Insulated wire and cable & Communication and energy wire and cable manufacturing & Electric wires and cables & Electrical equipment \\
\hline 7232 & Electrical insulating equipment & Communication and energy wire and cable manufacturing & $\begin{array}{l}\text { Other electrical devices and } \\
\text { parts }\end{array}$ & Electrical equipment \\
\hline 5714 & Hunting and sporting ammunition & Ammunition manufacturing & Ordnance & Firearms \\
\hline 69213 & Tanks,etc.for storage or manuf.use of aluminium & Metal tank (heavy gauge) manufacturing & $\begin{array}{l}\text { Metal containers, fabricated } \\
\text { plate and sheet metal }\end{array}$ & Sheet metal products \\
\hline 69222 & Casks,drums,etc.used for transport of aluminium & Metal Can, Box, and Other Metal Container (Light Gauge) Manufacturing & $\begin{array}{l}\text { Metal containers, fabricated } \\
\text { plate and sheet metal }\end{array}$ & Sheet metal products \\
\hline 69232 & Compressed gas cylinders of aluminium & Metal Can, Box, and Other Metal Container (Light Gauge) Manufacturing & $\begin{array}{l}\text { Metal containers, fabricated } \\
\text { plate and sheet metal }\end{array}$ & Sheet metal products \\
\hline 69885 & Stoppers,crown corks, bottle caps, of base metal & Crown and closure manufacturing and metal stamping & $\begin{array}{l}\text { Bolts, nuts, rivets and } \\
\text { springs }\end{array}$ & $\begin{array}{l}\text { Fabricated metal } \\
\text { products }\end{array}$ \\
\hline 69887 & Soldering \& welding rods, etc, of base metal & Other general purpose machinery manufacturing & Other metal products & $\begin{array}{l}\text { Fabricated metal } \\
\text { products }\end{array}$ \\
\hline 69894 & Articles of aluminium,n.e.s. & Other fabricated metal manufacturing & Other metal products & $\begin{array}{l}\text { Fabricated metal } \\
\text { products }\end{array}$ \\
\hline 8943 & Non military arms & Arms, ordnance, and accessories manufacturing & Ordnance & Firearms \\
\hline 9510 & Firearms of war \& ammunition thereof & Arms, ordnance, and accessories manufacturing & Ordnance & Firearms \\
\hline
\end{tabular}




\section{Definition of Terms of Trade}

Terms of trade (TOT) is commonly used to represent the competitiveness of countries in international trade. In this paper, we use the main three variants of TOT to calculate the ability of these four countries to get monetary, energy and environmental benefits in aluminum international trade.

Commodity terms of trade (CTOT) is used to analyze the profitability of countries which is defined as the ratio between a country's commodity export price and its import price. When the export price is larger than import price, CTOT is higher than $100 \%$. That means the country can get monetary value from a same product or product group's international trade.

Energy terms of trade (ETOT) and pollution terms of trade (PTOT) are used to measures the energy and environmental gains and losses that a country get from international trade. ${ }^{29}$ They are estimated by the ratio between a product or product group's CTP energy use and GHG emissions intensity of export and its CTP energy and GHG emissions intensity of import. When ETOT and PTOT are smaller than $100 \%$, the energy and environmental burden embodied in the export goods are lower than that in imported goods. The country can get energy and environmental benefits from other countries by international trade.

The higher TOT, the better a country's profitability. On the contrary, the lower ETOT and PTOT, the better a country's ability to get energy and environmental benefits from other countries. 


\section{Uncertainty analysis}

The results are mainly sensitive to the aluminum content of ACPs. We calculate the resource, monetary value, energy, and environmental burden in these four countries' aluminum trade under different aluminum contents (Figure S4). Results show that aluminum content affects the absolute value of four flows, but does not change the trends and directions of the four flows, suggesting that our broad conclusions hold robustly.
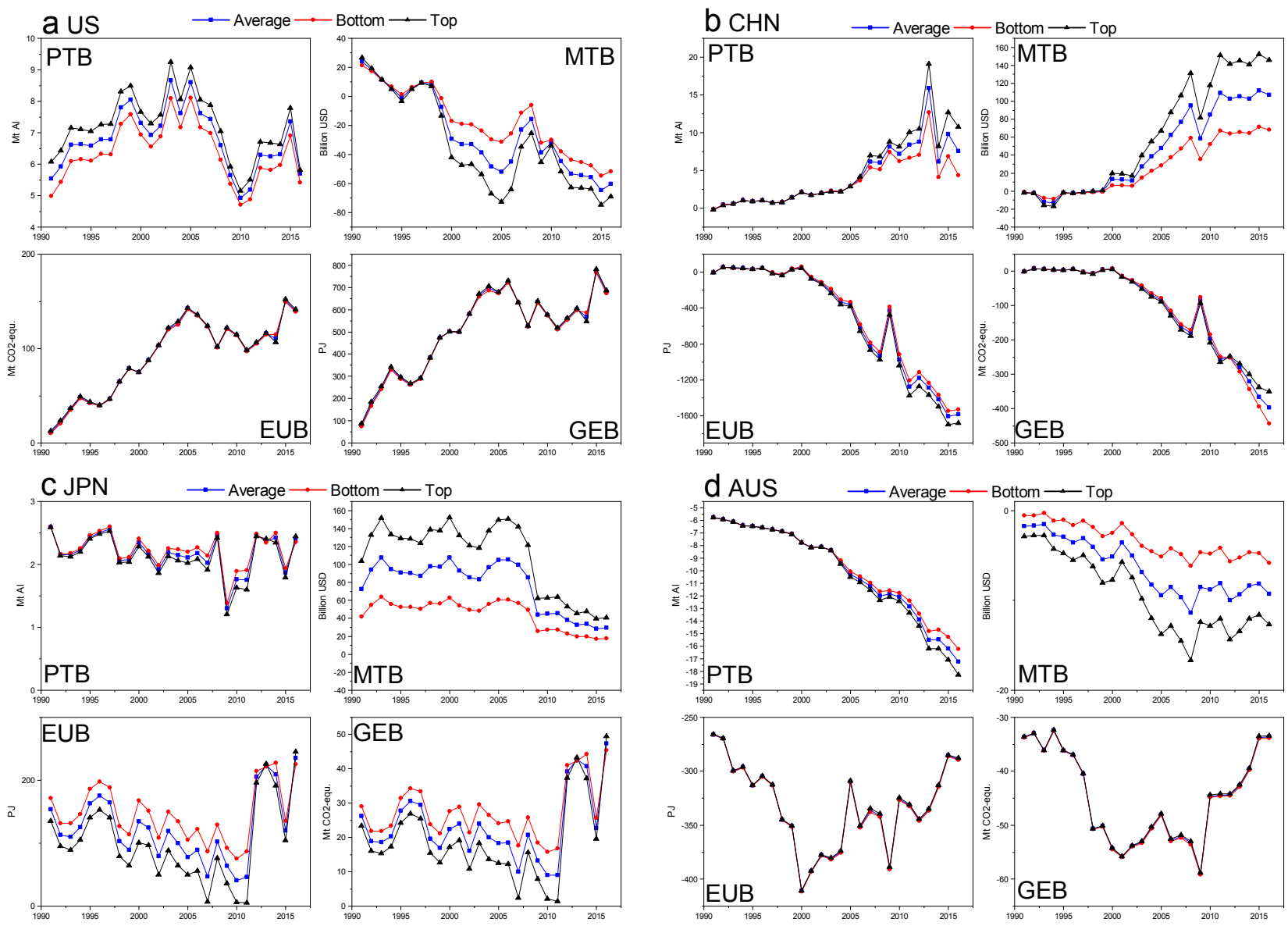

Figure S4 The average, bottom, and top value of PTB, MTB, EUB, and GEB for (b) China, (c) Japan, and (d) Australia from 1991 to 2016. 
$\because$ US $\longrightarrow \mathrm{CHN} \simeq \mathrm{JPN} \longrightarrow$ AUS
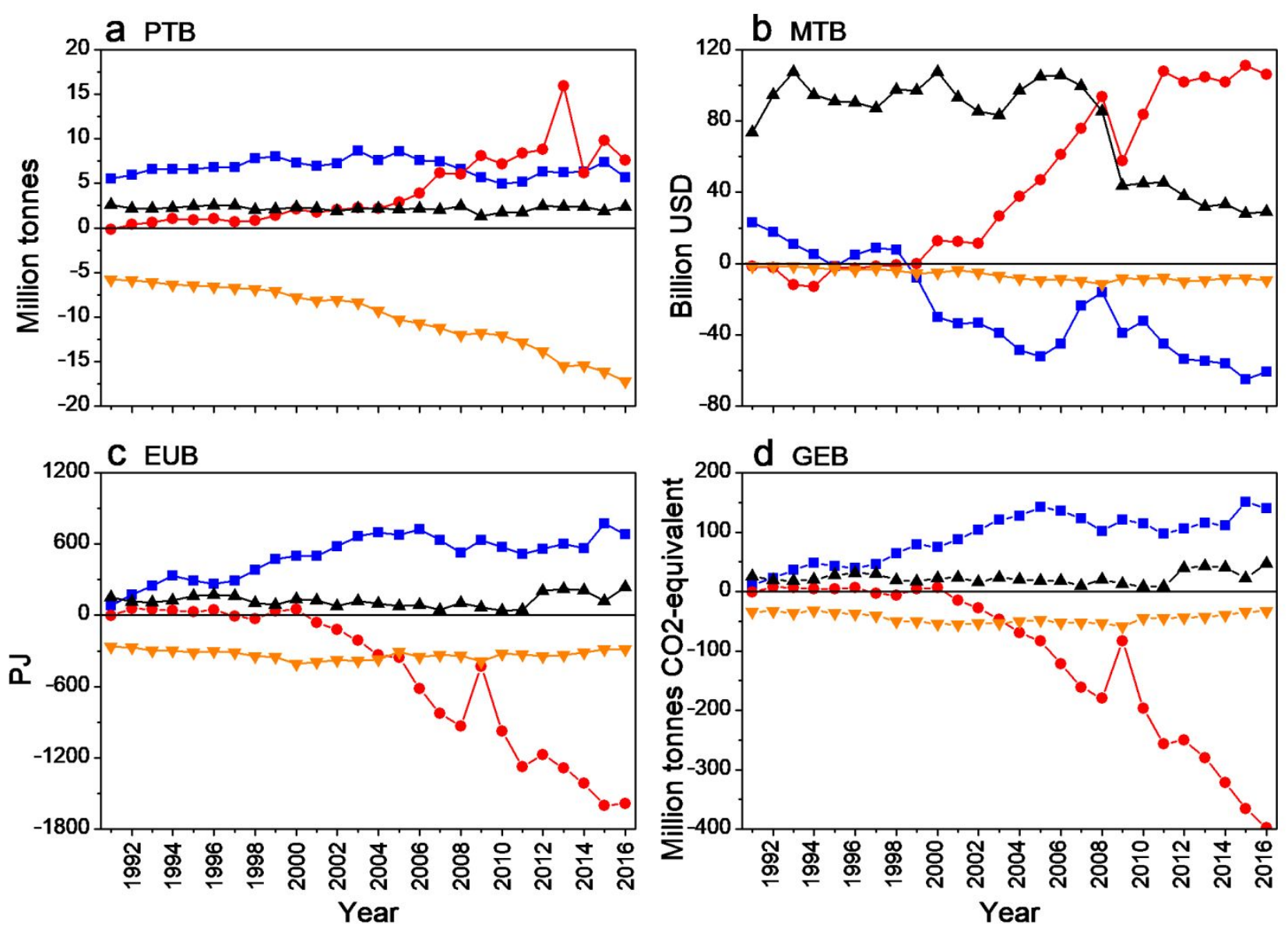

Figure S5 Aluminum trade balance in resource, economic, energy and environmental consequences for these four countries. 


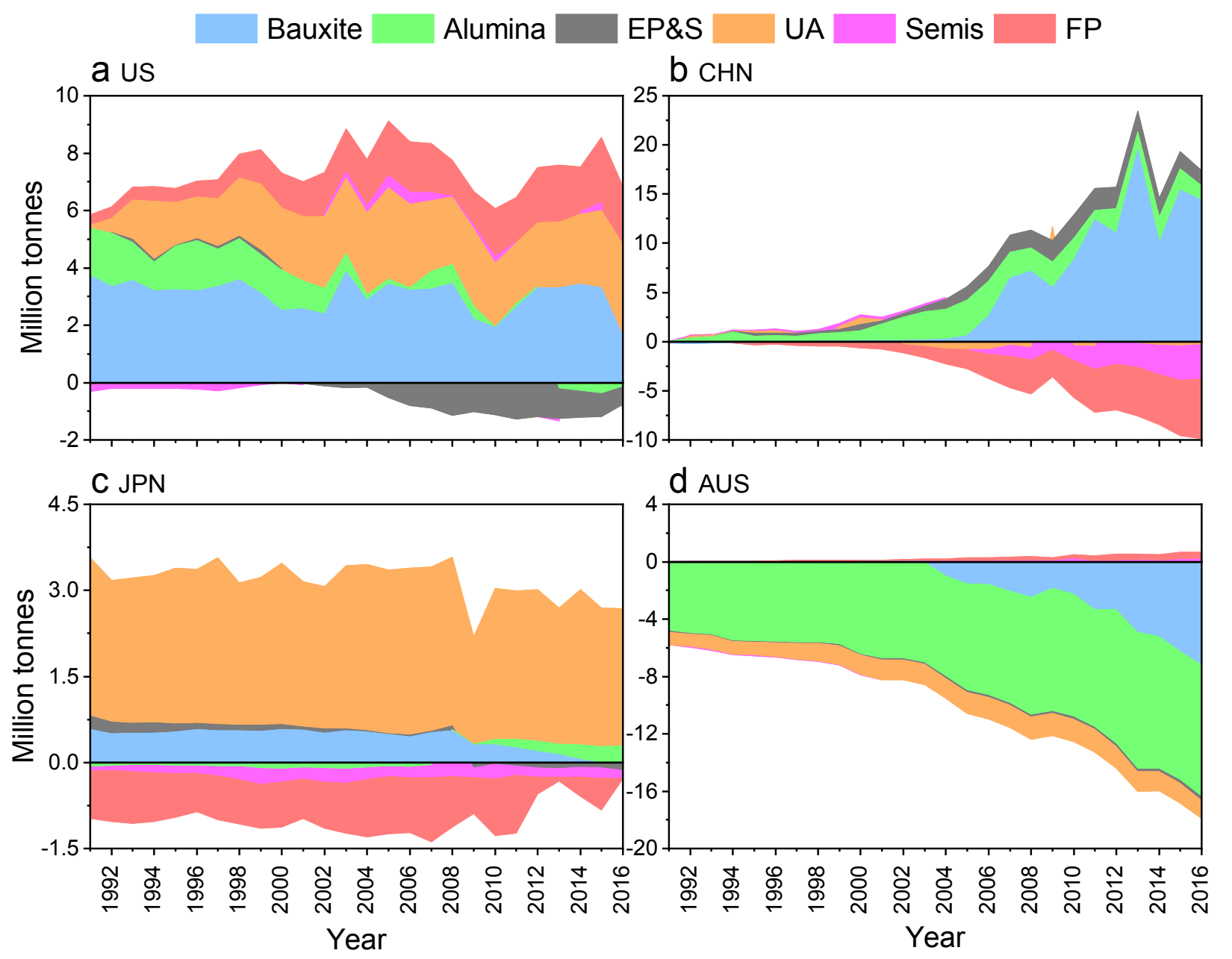

Figure S6 Net import of aluminum embedded in different product groups measured by mass for (a) the US, (b) China, (c) Japan, and (d) Australia from 1991 to 2016. EP\&S = EOL Products \& Scrap, $\mathrm{UA}=$ Unwrought Aluminum, Semis, $\mathrm{FP}=$ Finished Products. $\mathrm{Mt}=$ Million tonnes. 


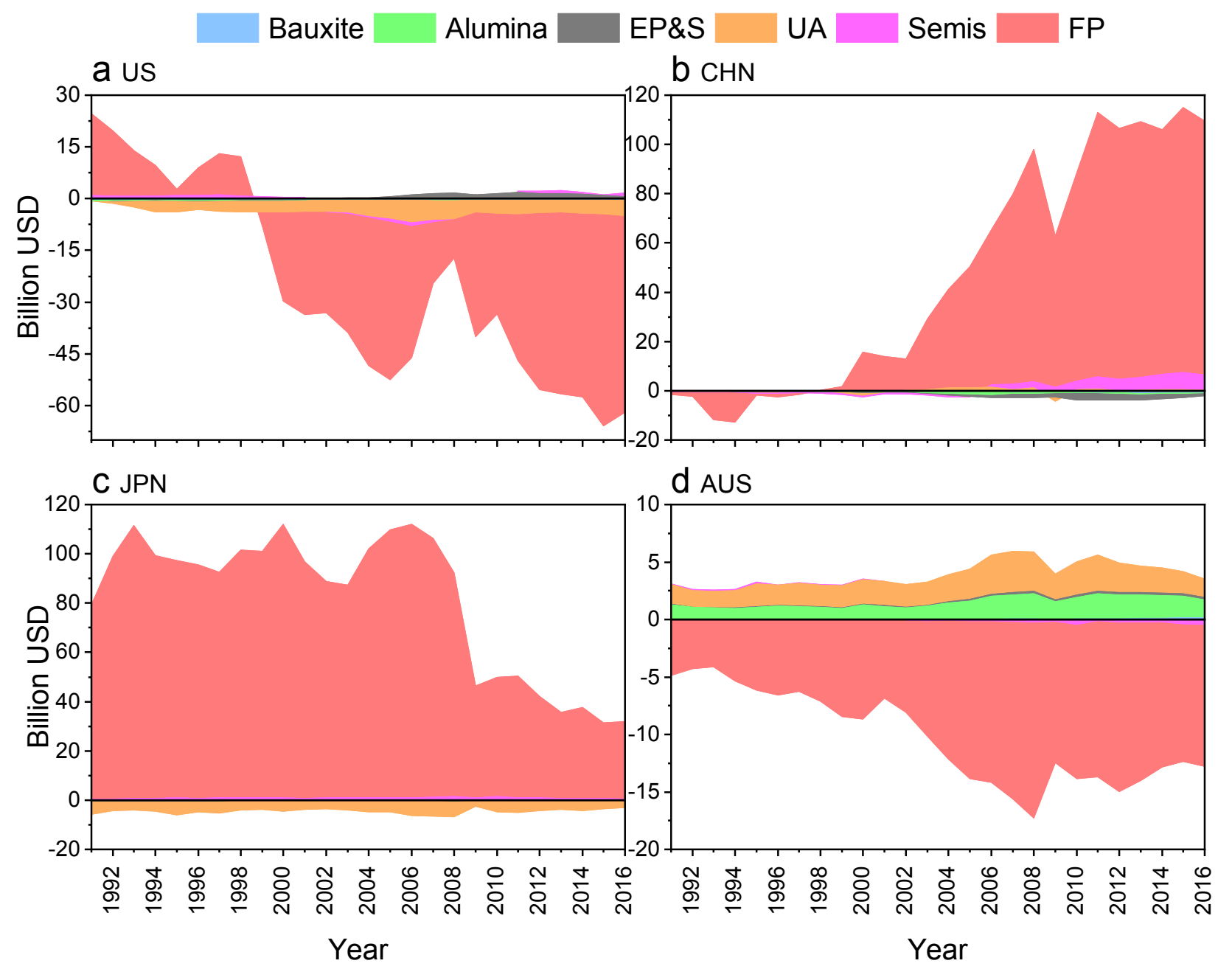

Figure S7 Money earned by trade of different ACP groups for (a) US, (b) China, (c) Japan, and (d) Australia from 1991 to 2016. EP\&S = EOL Products \& Scrap, UA = Unwrought Aluminum, Semis, $\mathrm{FP}=$ Finished Products 


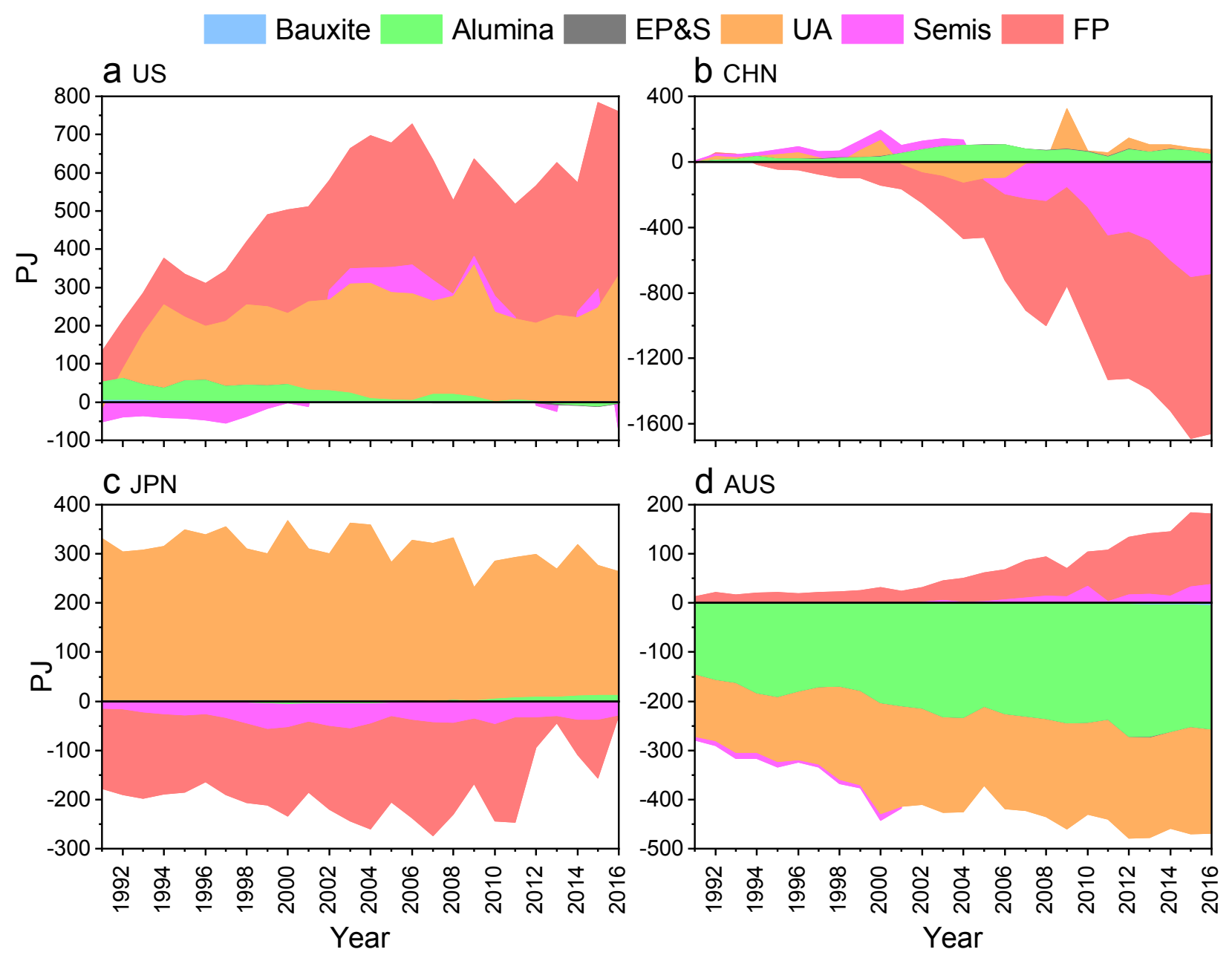

Figure S8 Net import of embodied energy in aluminum trade for (a) US, (b) China, (c) Japan, and (d) Australia from 1991 to 2016. EP\&S = EOL Products \& Scrap, UA = Unwrought Aluminum, Semis, $\mathrm{FP}=$ Finished Products. PJ $=$ Petajoule $=10^{15} \mathrm{~J}$. 

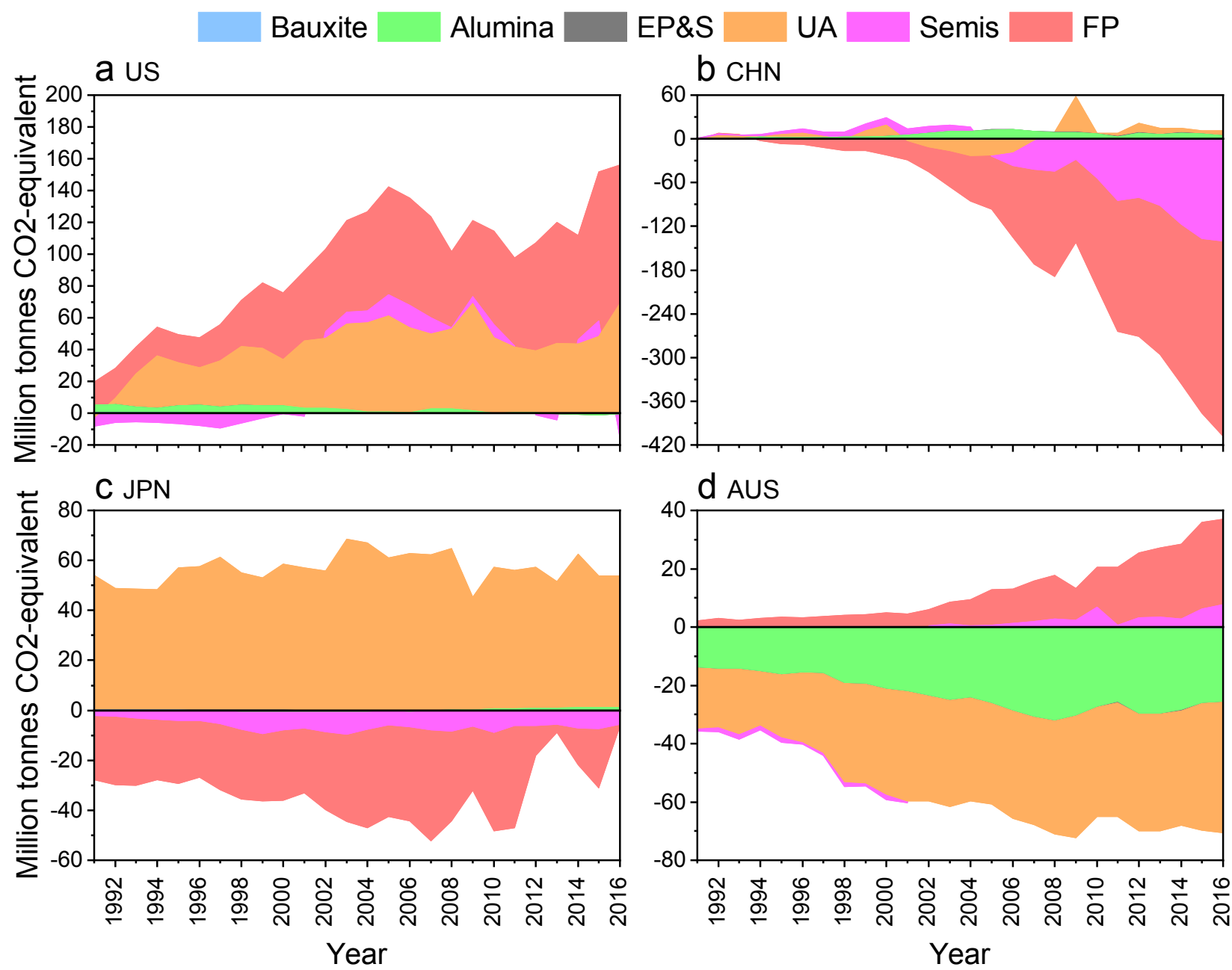

Figure S9. Net import of embodied GHG emissions in aluminum trade for (a) US, (b) China, (c) Japan, and (d) Australia from 1991 to 2016. EP\&S = EOL Products \& Scrap, UA = Unwrought Aluminum, Semis, $\mathrm{FP}=$ Finished Products 


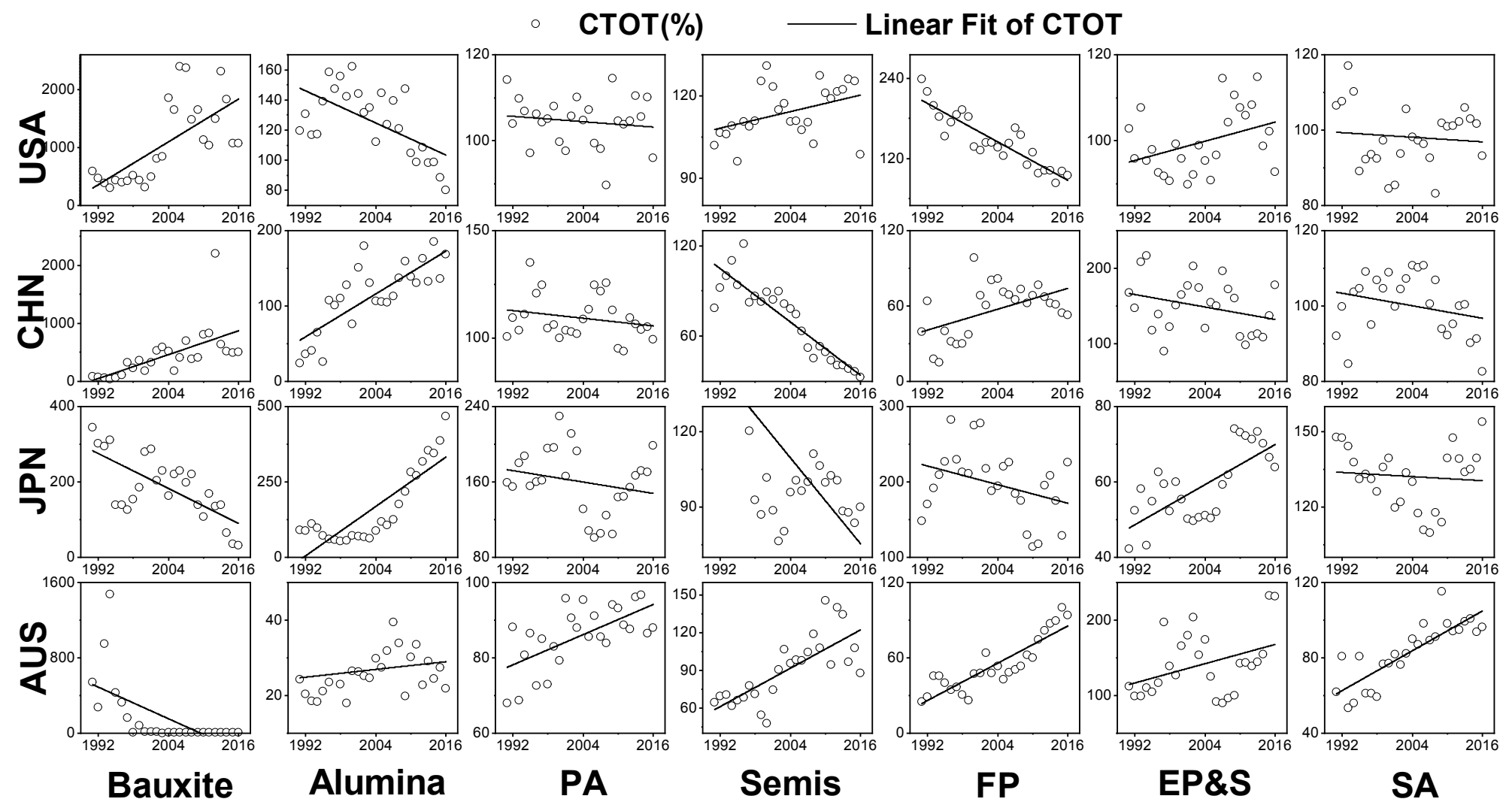

Figure S10 The seven ACP groups' commodity terms of trade of these four countries. CTOT = Commodity terms of trade; Linear fit of CTOT shows the trend of each of ACP's CTOT. 


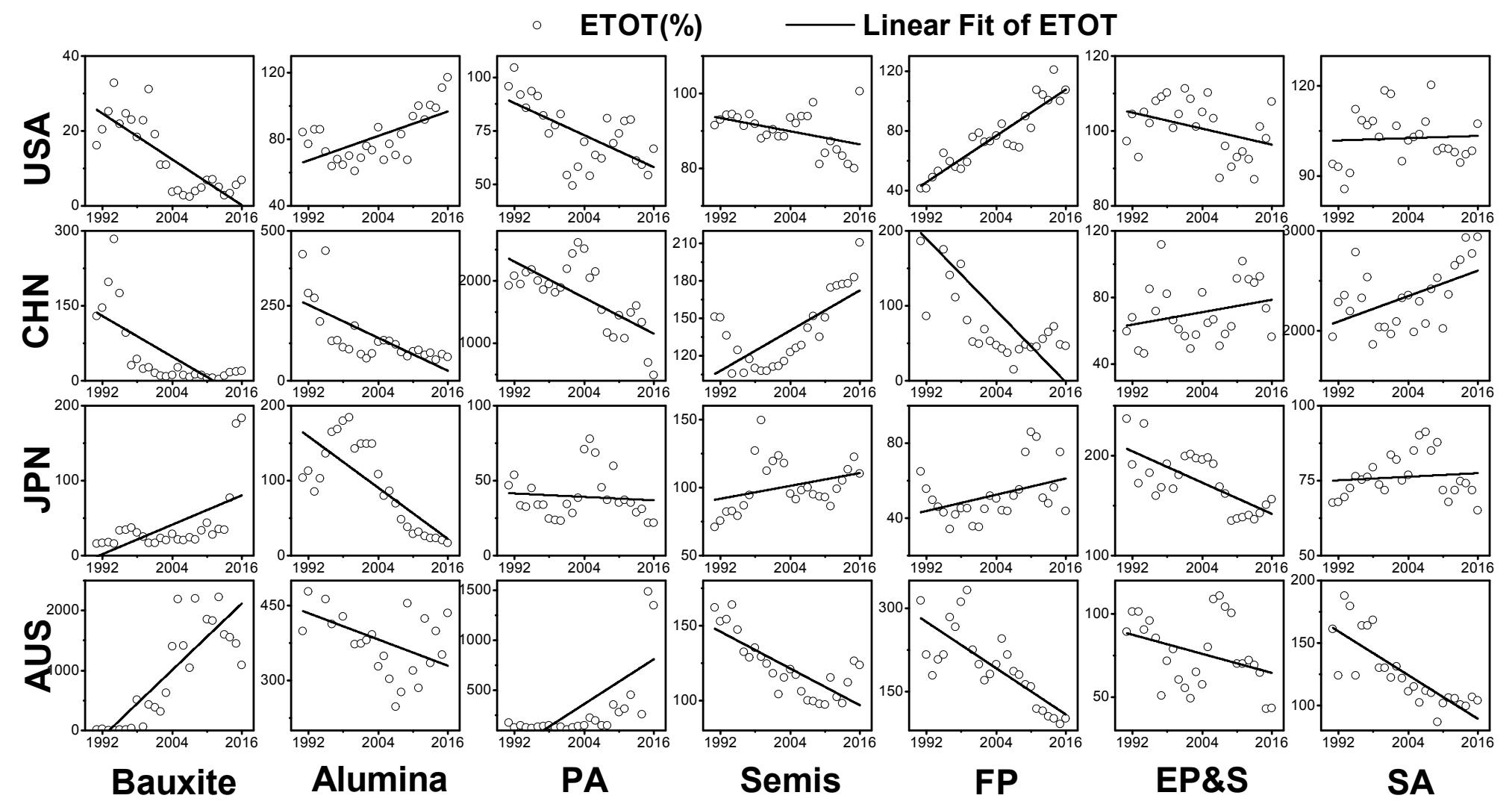

Figure S11 The seven ACP groups' energy terms of trade of these four countries. ETOT = Energy terms of trade; Linear fit of ETOT shows the trend of each of ACP's ETOT. 


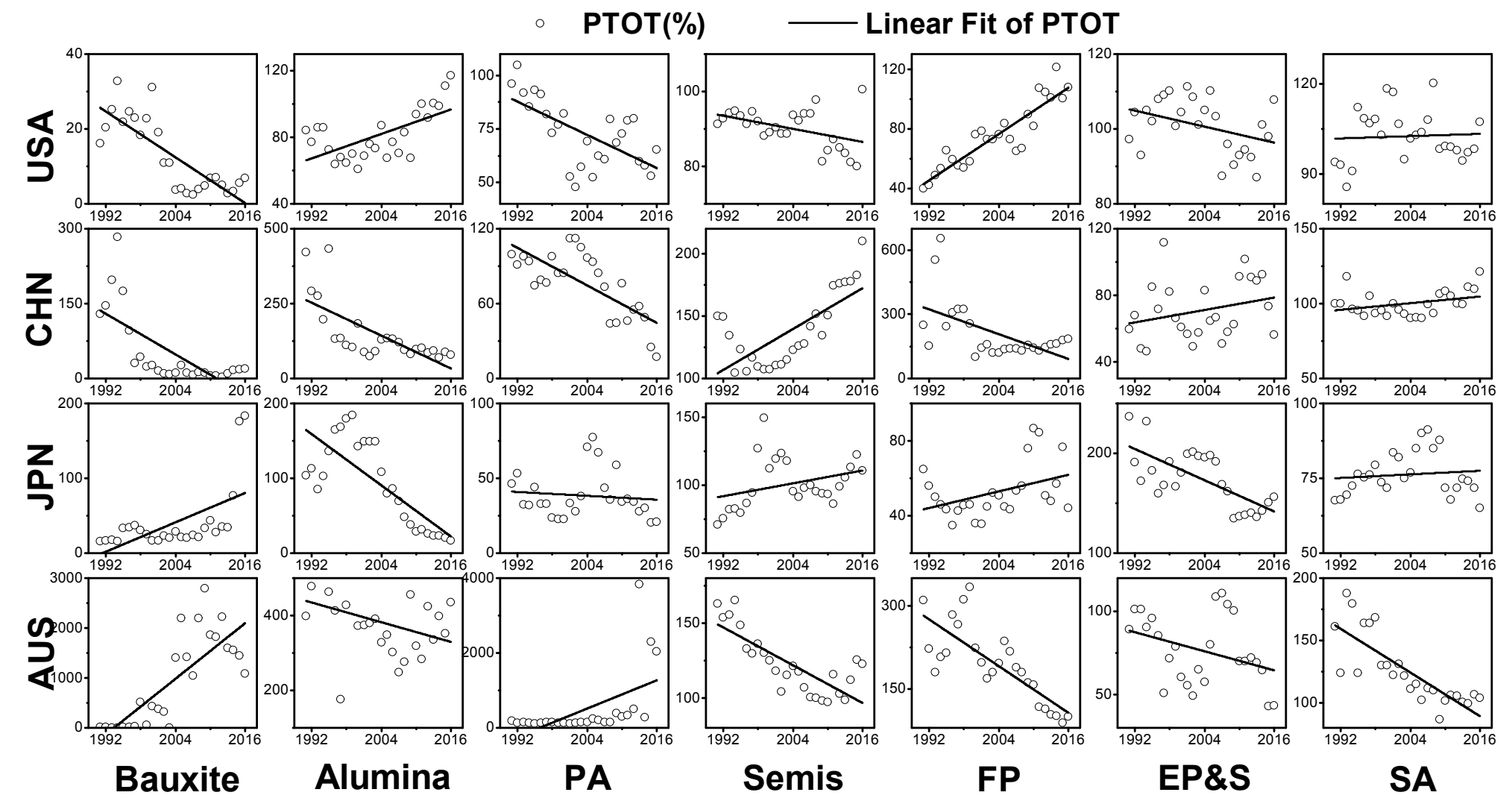

Figure S12 The seven ACP groups' pollution terms of trade of these four countries. PTOT = Pollution terms of trade; Linear fit of PTOT shows the trend of each of ACP's PTOT. 


\section{References}

(1) Chen, W.-Q.; Graedel, T. E. Dynamic analysis of aluminum stocks and flows in the United States: 19002009. Ecological Economics 2012, 81, 92-102. DOI: 10.1016/j.ecolecon.2012.06.008.

(2) Chen, W.-Q.; Shi, L. Analysis of aluminum stocks and flows in mainland China from 1950 to 2009: Exploring the dynamics driving the rapid increase in China's aluminum production. Resources, Conservation and Recycling 2012, 65, 18-28. DOI: 10.1016/j.resconrec.2012.05.003.

(3) Liu, G.; Bangs, C. E.; Müller, D. B. Unearthing potentials for decarbonizing the U.S. aluminum cycle. Environmental science \& technology 2011, 45 (22), 9515-9522. DOI: 10.1021/es202211w.

(4) Weiqiang, C.; S. H. I. Lei; Xiaoyu, C.; Yi, Q. Substance Flow Analysis of Aluminium in China for 1991-2007 ( I ):Trade of Aluminium from a Perspective of Life Cycle and Its Policy implications. Resources Science 2009, 31 (11), 1887-1897.

(5) AA. Life Cycle Inventory Report for the North American Aluminum Industry.

(6) AA. The Environmental Footprint of Semi-Finished Aluminum Products in North America.

(7) JAA. Aluminum and the Environment. https://www.aluminum.or.jp/environment/index.html (accessed 201906-13)

(8) Wu, J.; Wang, H.; Chen, W.; Shi, L. Quantifying energy consumption and greenhouse gas emissions of the primary aluminum industry in China 2010, 50 (3), 407-410.

(9) European Aluminium Association. Life-Cycle inventory data for aluminium production and transformation processes in Europe.

(10) European Aluminium Association. Environmental Profile Report for the European Aluminium Industry.

(11) European Aluminium Association. Environmental Profile Report for the European Aluminium Industry.

(12) International Aluminium Institute. Life Cycle Inventory of the Worldwide Aluminum Industry With Regard to Energy Consumption and Emissions of Greenhouse Gases_Paper 1_Automotive.

(13) International Aluminium Institute. Life Cycle Assessment of Aluminum: Inventory Data for the Worldwide Primary Aluminum Industry.

(14) International Aluminium Institute. Life Cycle Assessment of Aluminum: Inventory Data for the Primary Aluminum Industry.

(15) International Aluminium Institute. Global Life Cycle Inventory Data for the Primary Aluminum Industry 2010 DATA.

(16) International Aluminium Institute. Life Cycle Inventory Data and Environmental Metrics for the Primary Aluminum Industry.

(17) International Aluminium Institute. Primary Aluminium Smelting Energy Intensity. http://www.worldaluminium.org/statistics/primary-aluminium-smelting-energy-intensity/\#linegraph (accessed 2019-06-15).

(18) IPCC. IPCC Guidelines for national greenhouse gas inventories. Prepared by the National Greenhouse Gas Inventories Programme.

(19) U.S. Department of Energy, Office of Industrial Technologies. Energy and Environmental Profile of the U.S. Aluminum Industry.

(20) International Aluminium Institute. Primary aluminium smelting power consumption. http://www.worldaluminium.org/statistics/primary-aluminium-smelting-power-consumption/\#data (accessed 2019-06-20).

(21) International Aluminium Institute. Aluminium carbon footprint technical support document. http:// www.world-aluminium.org/media/filer_public/2018/11/22/carbon_footprint_technical_support_document_v1_ published.pdf.

(22) International Aluminium Institute. Calculating direct GHG emissions from primary aluminum production calculation worksheets. http://www.ghgprotocol.org/sites/default/files/ghgp/

Aluminium\%20Sector\%20GHG\%20Workbook\%20-\%20version\%202_1_0.xls. 
(23) International Aluminium Institute. IAI Statistical Survey Forms: Energy. http://www.world-aluminium.org/ media/filer_public/2018/04/17/2018_iai_smelter_anode_energy_survey_form_841DZLT.xlsx.

(24) Leontief, W. Environmental Repercussions and the Economic Structure: An Input-Output Approach. The Review of Economics and Statistics 1970, 52 (3), 262. DOI: 10.2307/1926294.

(25) BEA. Benchmark Input-Output Data. https://www.bea.gov/industry/benchmark-input-output-data (accessed 2019-09-10).

(26) MIC. Input-Output Table for 2005 (Comprehensive commentary). https://www.soumu.go.jp/toukei toukatsu/data/io/005index.htm (accessed 2019-09-10).

(27) ABS. 1292.0 - Australian and New Zealand Standard Industrial Classification (ANZSIC), 1993. https:// www.abs.gov.au/ausstats/abs@.nsf/66f306f503e529a5ca25697e0017661f/

82031A289B5EA094CA25697E0018FB48?opendocument (accessed 2019-09-12).

(28) Eurostat. Index of correspondence tables. https://ec.europa.eu/eurostat/ramon/relations/index.cfm? TargetUrl=LST_REL\&StrLanguageCode=EN\&IntCurrentPage=1 (accessed 2019-05-12).

(29) Antweiler, W. The Pollution Terms of Trade. Economic Systems Research 1996, 8 (4), 361-366. DOI: 10.1080/09535319600000027. 